\title{
Erken Cumhuriyet Döneminde Sağlıklı Bireyin İnşası: Pronatalist Politikalar, Çocuk Sağlığı ve Verem
}

\author{
Ceren Gülser ilikan Rasimoğlu' ${ }^{1}$
}

Öz

Bu makale, Erken Cumhuriyet dönemi Türkiye'sinde nüfus meselesini çocuklara ve çocukların sağlı̆ına atfedilen anlamlar üzerinden değerlendirerek incelemektedir. Makalede pronatalist politikalar ile vatandaşlık eğitiminin iç içe geçtiği bir halk sağlığı anlayışı anlatılmakta; verem konusu özelinde dönemin sağlık sorunlarına üretilen çözümler tartı̧̧ılmaktadır. Hekimler tarafindan dönemin sağlık propagandası dergilerinde kaleme alınan yazılar üzerinden 20. yüzyıl ile beraber halk sağlığı uygulamalarının temel odak noktasında yaşanan dönüşüm, kişisel hijyenin sosyal sorumluluk alanına itilişi ve modern tıp tarafindan sınırsız bir müdahale alanına dönüştürülmesi konu edilmektedir.

Anahtar Kelimeler

Verem • Sağlık sosyolojisi • Nüfus • Erken Cumhuriyet Dönemi • Çocuk sağlığı • Pronatalist politikalar • Öjeni - Tip tarihi

Constructing the Healthy Individual in the Early Republic: Pronatalist Policies, Child Health, and Tuberculosis

\section{Abstract}

This article studies the issue of population in Turkey during the Early Republican Period by assessing the meanings attributed to children and children's health. The article discusses the approach to public health, wherein pronatalist policies and citizenship education are intertwined, and deliberates the solutions produced for the health problems of the period by focusing on the case of tuberculosis. By examining articles physicians wrote in health propaganda journals of the period, this article discusses how the focus of public health practices transformed in the 20th century, the direction personal hygiene took towards an area of individual responsibility, and how modern medicine was transformed into an unlimited field of intervention.

\section{Keywords}

History • Medical sociology • Population • Early Republican Period • Child health • Pronatalist policies • Eugenics $\bullet$ History of medicine 


\section{Extended Summary}

As in many other countries, public health practice during Turkey's Interwar Period was focused on children. The result of socially redefining the body since the late 18th century had positioned health policies at a leading position. The influence of positivism in every field resulted in glorifying the sciences that study society and paved the way for interventions in areas such as crime, poverty, and productivity. In addition, this interest was taken over by the republic and reshaped in the context of constructing the nation and citizenship.

This article explores the relationship between pronatalist policies and citizenship education in the Early Republican Period. It analyzes the meanings attributed to the children of the country and reveals the relationship between the fight against tuberculosis and these meanings. The study has not considered childhood experiences from an insider perspective nor has it included children's voices as a source. Instead, the article focuses on the meanings and biopolitical discourses adults and physicians in particular imposed on children in the Late Ottoman and Early Republican Periods, historicizing these starting from the Late Ottoman Period.

The main sources used in the article are texts that discuss the population problems of the period which physicians produced in the first quarter of the century. In this period, physicians occupied an important place in state cadres and played a decisive role in producing health and population policies. Therefore, the texts written by the members of this profession provide information on how the population problem was handled in the eyes of the state. The texts generally include articles on health, epidemics, and children deaths, as well as chapters prepared for children to read in publications from the Istanbul Society for the War against Tuberculosis.

The article discusses the impact of the idea of biopolitics on the newly founded Turkey in terms of children's health and tuberculosis. It establishes on a historical basis the process of modern medicine's expansion into areas that intervened in individuals' daily lives and its engagement in population debates. For this purpose, the study first discusses the theoretical framework of the relationship between the national population problem and children's health, then describes the course of concrete discussions about children's health in the Late Ottoman and Early Republican Periods, and lastly explains the place tuberculosis occupied in the field of children's health, the forms of health propaganda, and the discourse produced over the citizen child.

In the Early Republican Period, population policies were shaped to support pronatalism and these policies were able to be implemented with the support of the educated elites of the period, especially physicians. Physicians and bureaucrats attributed as much importance to propaganda as they did to inaugurating a national health system because they believed that health propaganda could prevent epidemics 
and decrease child death rates. But health propaganda, rather than mere health, also included the discourse produced for realizing the civilization project that was envisioned as an inherent part of nationalization. In other words, being able to behave healthily also became one of the basic skills expected of a responsible citizen.

Three elements have been found that made this transformation possible: medical, scientific, and political. The medical aspect involved transitioning from an understanding of public health based on sanitary conditions to one based on personal hygiene. New public health practices spread the idea of the risk of transmitting diseases from a particular area to all areas, and thus the area medical knowledge was able to reach became unlimited. Observation and intervention in the field of the infinite danger zone included new administrative techniques and discourses; as a result, citizenship education was able to be included in health education.

Secondly and scientifically, although germ theory had been produced in the previous century, it had only been able to become widespread in the 20th century; after this, the transfer of hygienic practices to all strata of society could finally be expected and targeted. The presence of microbes provided and justified scientific grounds for suggesting compliance with personal hygiene rules to prevent diseases, as in the case of tuberculosis. In this way, the social causes of the disease were rendered invisible and a significant part of the fight against tuberculosis could be transferred away from the responsibility of the state to individual responsibility and institutional volunteerism.

Thirdly and politically, the overlap of nationalist and political propagandas had a historical background. Insufficiency of the population since the 19th century had been considered as the crucial concern the ruling elites had to concretely solve in terms of security and labor shortages in the Interwar Period. After the demographic transformation and destruction of fundamental institutions such as family and education that had been provoked by the cultural crisis, physicians found a domain where they could impose their power of knowledge to restore these institutions.

In this context, the solution to the population and cultural crises brought the new family and new woman forward and at the same time produced a language based on the understanding of the citizen child: healthy children were indispensable for maintaining the regime and nation. In this sense, pronatalist policies merged with eugenics through the fear of degeneration, at least in the eyes of physicians and bureaucrats. Parents who could not provide children with the environment and knowledge necessary for a healthy life were accused on a scale that ranged from neglect of national duty to murder. In the case of tuberculosis, both adults and children were expected to educate each other. Only then could current or future adults become citizens who were healthy-bodied, healthy-minded, moral, and civilized. 


\section{Erken Cumhuriyet Döneminde Sağlıklı Bireyin İnşası: Pronatalist Politikalar, Çocuk Sağlığı ve Verem}

Çocuk Doktoru Behçet 1929 senesinde yayımlanan “Çocuk Bakımı” başlıklı makalesinde yeni nesle verilecek terbiyelerden en önemlisinin çağın ihtiyaçlarına göre yetiştirilmesi olduğunu söylüyordu. Hem Himaye-i Etfal (Türkiye Himaye-i Etfal Cemiyeti) polikliniğine hem de özel muayenehanelere gelen çocukların durumundan Doktor Behçet'in çıkarımı, çocuklara iyi bakılmadı̆̆1 yönündeydi. Doktor Behçet, çocuğunu muayeneye getiren bir kadının, çocuğunun ne sıklıkta tuvalete gittiği sorusuna cevap vermemesini lakaytlik olarak nitelendiriyor, "milletimizin her ferdinde bilhassa kadınlarımızda çocuklarımızla hakiki ve samimi alaka uyandırmak ve bu yolları te'min etmek bize düşen en esaslı bir borçtur" diyordu. Bu ilgiyi sağlamadan verilen her tür bilimsel telkinin yok yere olduğu ifade ediyordu: "Eğer biz ilmin fennin bu günkü feyizli neticelerini annelere hakkı ile hazm ettiremezsek çocuklarımızın sağlam ve hastalıksız büyümelerine imkân yoktur.” Bunun için kız okullarında öncelikle amelî çocuk büyütmenin öğretilmesi gerektiğinin altını çiziyordu. "Hanım kızların" bu eğitim sonucunda yetiştirecekleri çocuklar daha güçlü olacak ve daha uzun yaşayacaklardı (s. 3).

Doktor Behçet'i kaygılandıran bu durum döneminin eli kalem tutanları tarafından sıklıkla dile getirilen bir endişeydi. İki savaş arası dönemde halk sağlığı uygulamaları birçok ülkede olduğu gibi Türkiye' de de çocuklara odaklanmıştı. Bedenin geç 18. yüzyıldan itibaren toplumsal olarak yeniden tanımlanmasının 1920'li ve 1930'lu yıllar Türkiye'sindeki karşılığı, kendi çağdaşlarıyla paralellik arz edecek şekilde sağlığın başat konuma alınması olmuştu. Pozitivizmin her alanda etkisini göstermesi, toplumu konu alan bilimlerin yüceltilmesi ve suç, yoksulluk, üretkenlik gibi meselelerin müdahale edilebilir hale gelmesi ile sonuçlanmıştı. Bu ilgi Cumhuriyet tarafından devralınarak ulus ve vatandaşlık inşası bağlamında yeniden şekillenmişti.

Bu makale, Erken Cumhuriyet Dönemi'nde pronatalist politikalar ile vatandaşlik eğitiminin izdüşümlerini aramaktadır. Makalede ülkenin çocuklarına yüklenen anlamlar çözümlenerek verem hastalığıyla mücadelenin bu anlamlarla ilişkisi ortaya konmaktadır. Çocukluk deneyimlerine içeriden bakılmamakta, dayandığı kaynaklar itibariyle çocukların sesine yer verilmemektedir. Onun yerine geç Osmanlı ve Erken Cumhuriyet dönemlerinde yetişkinlerin ve özellikle hekimlerin çocuğa yükledikleri anlamlara ve çocukla ilgili ürettikleri biyopolitik söylemlere odaklanmakta ve bu anlam ve söylemleri geç Osmanlı döneminden itibaren tarihselleştirmektedir.

Erken Cumhuriyet döneminde demografik dönüşümün yarattığı endişe, dönemin politikalarında belirleyici olduğu için bu makalede bahsedilen dönüşümün sağlığa ilişkin üretilen söylemlerdeki karşılıkları aranmıştır. İleride açıklanacağı gibi sağlık alanı, demografik dönüşümün önemli belirleyicilerinden biri olarak ortaya çıkmıştır. Özellikle 
Cumhuriyet' in kuruluşundan önce yaşanan on yıllık savaş dönemi, doğum ve ölüm hızları ile salgın hastalıkların görülme sıklığı üzerinde etkili olduğundan, Cumhuriyet döneminde vatandaşlık inşa edilirken sağlıklı bireyin de inşa edilmesi gerekmiştir. Dönemin en yaygın olarak görülen hastalıklarından biri olan verem, kötüleşen yaşam koşullarında daha hızlı yayıldığı için tüm nüfusu tehdit etmiştir. Dahası, kalabalık ortamlarda veremin yayılması iyice kolaylaştığından, okul çocuklarında hastalığın yaygınlaşması sonucunda verem, Cumhuriyet kadroları ve dönemin hekimlerinin öncelikli sorunlarından biri haline gelmiştir. Bu nedenle makale çocuklarda verem olgusunun erken Cumhuriyet döneminde nasıl ele alındığını incelemektedir.

Makalede kullanılan temel kaynaklar, hekimler tarafından yüzyılın ilk çeyreğinde üretilmiş olan ve dönemin nüfus sorununun tartışıldığı metinlerdir. Bu dönemde hekimler devlet kadrolarında önemli yer işgal etmiş, sağlık ve nüfus politikalarının üretilmesinde belirleyici rol oynamışlardır. Bu nedenle hekimlerin kaleme aldığı metinler, devletin nazarında nüfus sorununun nasıl ele alındığına ilişkin bilgi de vermektedir. Bu çalışmada genel olarak sağlık, salgın hastalıklar, çocuk ölümleri üzerine yazılmış metinlere yer verilmekte, ayrıca özel olarak İstanbul Verem Savaş Derneği'nin yayınlarında çocukların okuması için hazırlanan bölümler tartışılmaktadır.

Makalede kuruluş dönemindeki Türkiye Cumhuriyeti'nde biyopolitika kavramının karşı1lı̆̆ aranmaktadır. Modernleşen tıbbın nüfus tartışmaları üzerinde söz sahibi olmaya başlayıp bireyin gündelik yaşamına müdahale alanını genişletme süreci tarihsel bir zemine oturtulmuştur. Bu nedenle nüfus tartışmalarının 19. yüzyıldan itibaren aldığı seyrin izleri takip edilmekte ve sıhhi şartların değiştirilmesinden kişisel hijyene doğru ilerleyen süreçte yetişkin ve çocuklara atfedilen sorumlukların tıbbileşen dili tahlil edilmektedir. Bu amaçla makalede ilk olarak ulusal nüfus davası ile çocuk sağlı̆ğ arasındaki ilişkinin teorik çerçevesi tartışılmakta, ikinci olarak geç Osmanlı ve Erken Cumhuriyet dönemlerinde çocuk sağlığına yönelik somut tartışmaların seyri betimlenmekte ve son olarak verem hastalığının dönemin çocuk sağlı̆̆ı alanında işgal ettiği yer ve sağlık propagandasının uygulanış biçimleri ile ürettiği vatandaş çocuk temelli dil anlatılmaktadır.

\section{Nüfus Davasının Çözümü ve Vatandaşlık İnşasının Odağında Çocukların Sağlığı}

Türkiye'de erken Cumhuriyet döneminde nüfus konusunun tartışılması dönemin sağlık politikalarının çocuk sağlığı konusunu hangi parametrelerle değerlendirdiğini, dolayısıyla çocukluk ve çocuğa dair açık ve zımni algıların nasıl oluştuğunu sorgulamayı gerektirmektedir. Bu noktada, farklı sosyokültürel bağlamlarda farklı şekillerde tasavvur edilen çocuk ve çocukluk kavramlarının öneminin altını çizmek gerekmektedir (Brady, Lowe \& Olin Lauritzen, 2015, s. 173). Yeni çocukluk çalışmalarında çocukluk ve yetişkinlik kategorileri ilişkisel olarak görülmektedir. Nesilsel düzen (generational 
order) kavramına göre modern toplumlarda sosyal bir kategori olarak çocukla ilişkilendirilen bir toplumsal düzen bulunmaktadır ve çocuklar hem kendilerinin hem de başka kişilerin gündelik ilişkileri ve yaşam seyrinin gündelik inşasına dâhil olmaktadırlar. Bu görüş Ariès'nin (1962) çocukluğun ayrı bir kategori olarak görülmesini tarihselleştirdiği çalışmasının açtığı yoldan ilerlemektedir. Böylelikle çocukluk ve yetişkinlik kategorilerinin ancak birbiriyle var olduğu ve aralarındaki ilişkinin kuşaklar arasında tekrar tekrar üretildiği düşünülmektedir (Alanen, 2009, s. 160-161). Her şeyden evvel modern dünyada çocukluk, çocuğun yetişkinlerden ayrı bir özne olduğu düşüncesine dayanmaktadır ve Ariès'nin altını çizdiği gibi modern dünyada çocukluğa ilişkin temel gelişmelerden biri, yetişkinlere biçilen ahlaklılaştırma görevidir (Corsaro, 2015, s. 68).

Çocuğun yetişkinlerin dünyasından farklı bir dünyada yetiştirilmesi gerektiği fikri Batı'da 16. yüzyıldan itibaren hâkim olmaya başlamış, 18. yüzyılda gıda, tıp ve üretim teknolojilerindeki yeniliklerle eşzamanlı olarak çocuk bakımı giderek profesyonelleşmiş, hijyen ve çocuk bakımı ayrı birer alan haline gelmişti. John Locke ve Jean Jacques Rousseau ile Batı düşüncesinde çocuğun eğitilebilir ve eğitilmesi gerektiğine yönünde görülen kırılma çocuğun yetişkinler dünyasına yerleşmesine katkıda bulunmuştu (Öztan, 2012, s. 20-25). Yine de bu makalenin esas konusunu da oluşturan vatandaş çocuka geçiş esasen 19. yüzyılda gerçekleşmiş 20. yüzyılda ise yerleşikleşmişti. Fransız Devrimi'nin getirdiği ideallerle ve 19. yüzyıl reformlarıyla aile ve çocuk bütünüyle ulusa ait olarak görülmeye başlanmış ve ebeveynlerin çocuklarını ulus devletin beklentilerine göre yetiştirmesi gerekmeye başlamıştı (Öztan, 2012, s. 26; Robertson, 2006, s. 407).

Çocuğun bir yatırım nesnesi olarak algılanması bağlamında sağlık ve hastalık konusu daha 1880'lerde politik bir zemine oturmuştu (Hendrick, 1997, s. 39). Çocuklar devletin ve toplumun geleceği olarak görülmeye başlanmış, çocuklarla ilgili çok sayıda kitap ve dergi çıkarılmaya başlanmıştı. Bu yayınlarda çocukların geliştirilmesine yönelik Batı'dan gelen fikirler tartışılmaya başlanmış, bir yandan da klasik dini ve örfi kaynaklara başvurulmaya devam edilmişti (Araz, 2013, s. 176).

"Geleceğin vatandaşı" olarak çocuklara yatırım yapılması gerekiyordu ve çocuklar hep "beklemedeki vatandaşlar" durumundaydı (King, 2016, s. 390-393; Schmidt, 2013, s. 174-175). Hendrick (1994) çocukları genellikle "var olan" değil, ileride yetişkinliğe aday olmaları düşüncesi doğrultusunda "gelecek olan" olarak değerlendiriliyordu. Potansiyel yetişkin olarak görülen çocuklara, yetişkinlerden beklenenlerin değişimine paralel olarak özellikle yüzyıl dönümünden itibaren sadece dini ya da geleneksel çerçeveden değil aynı zamanda milliyetçi çerçeveden de bakılmaya başlanmış, çocuklar ulus devlet inşa sürecinin bir parçası olarak algılanmışlardı. Çocukluk kavramının bu şekilde tahayyül edilmesinin sonucu olarak yüksek doğurganlık oranları ve çocuk 
ölümü yönetici elitlerin önemli bir davası haline gelmişti (Gürsoy, 1995, s. 199). Geleceğin sağlıklı vatandaşlardan oluşmasını temin etmeye çalışırken bu çocukların aynı zamanda ulusal kimlik kazanması bekleniyor; fakat beklentiler ülkeden ülkeye farklı1ık gösteriyordu. Örneğin, iyi bir İngiliz ya da Türk vatandaşı yaratma isteğinin zemini İngiltere'de refah devleti, yoksulluk ve Büyük Buhran ekseninde tartı̧sılırken (Hendrick, 1994; King, 2016, s. 400) Türkiye'de ağırlıklı olarak medenilik, cehalet ve sağlıkta bireysel sorumluluklar üzerinden değerlendiriliyordu.

Çocuk bakımı söz konusu olduğunda konunun yegâne muhatabı anneler olarak algılanıyor ve annelik rasyonel ve standartlaştırılan çizgilerle şekillendiriliyordu. Birdenbire anneler terimlere, mamalara, çizelgelere uyacak şekilde donanmış; vitaminler ve bakterilere örülmüş bir terminolojiye hâkim olmakla sorumlu kılınmışlardı. Daha 19. yüzyıldan itibaren Avrupa'da yeni doğan çocukların taşraya sütannelere gönderilmesi geleneği kırılmaya çalışılıyor, annelere çocuklarını emzirmeleri öğütleniyordu. Bebeğini kendisi emziren kadın figürü orta sınıf ailelere yönelik aile birliğini yüceltici söylemin hâkimiyetinin işaretiydi (Robertson, 2006, s. 410). ${ }^{1}$

Bu süreçte annelik "bilimsel annelik" olarak nitelendiriliyordu ve iyi bir annenin içgüdülerini dinlemesinin yeterli olacağı fikri terkediliyordu. Bundan böyle mutlu ve sağlıklı çocuk ancak röntgen, ilaçlar, telefon, otomobil, filmler, kadının evde emek süresini azaltan cihazlar gibi bilimsel buluşlar aracıllğıyla yetiştirilebiliyor, bir bütün olarak annelik ve ev kadınlığını bilimsellik çerçevesine taşıyordu. İçü̈düsel annelikten bilimsel anneliğe geçişin temelindeki düşünce, bilim ve teknolojinin yaşamın ilerlemesine sebebiyet sağladığı gibi çocuk yetiştirmekte de kullanılabileceğiydi (Thurer, 1995, s. 225-226). Bu annelik türü çocuğa yönelik uyku, beslenme ve tuvalet rejimleriyle belirleniyor, propaganda yayınlarında yetişkinlere yönelik olarak dönemin tıbbi kaynaklarına ve haberlerine yer veriliyordu (Hendrick, 1997, s. 28).

Anneliğin bilimselleşmesinde bilim ve teknoloji kadar ailenin krizi de etkiliydi. Aile kurumu tehdit altında görüldüğünden Amerikan toplumu da dâhil olmak üzere pek çok toplumda çocuksuz evliliğin eksik olduğuna yönelik propaganda yapıllyor ve konu "doğurganlık ahlakı" olarak kurgulanıyordu (Glenn, 1994, s. 9). Psikoanalitik teori "normal" kadının çocuk istediğine ve anneliğini reddedenin kadınlığını da reddettiğine dair tezler üretiyordu (Glenn, 1994, s. 9). "Yeni Kadın" çalışmayı ve eğitimi seçmeye başlamış ve bu durum öjenistler için tehdit oluşturmaya başlamıştı. Artık uygarlığın korunmasından bahsediliyordu. Nihayetinde 20. yüzyıl doğurganlık ahlakı, evlilik ve anneliği kadınlığın temel amacı olarak teşvik ediyordu (Kline, 2011, s. 124-127).

$\mathrm{Bu}$ kaygıların altında toplumların dejenere olabileceği korkusu yatıyordu. Dejenerasyon teorisi 17. yüzyıl Avrupasında Protestan akımla beraber başlamış

1 Yine de annelerin bu programlara ne kadar uyduğu belli değildir (Hendrick, 1997, s. 29). 
1830" ara gelindiğinde orta sınıf "dejenere"lerin (yoksul, suçlu, fahişe, alkolik, psikotik, zekâ geriliği olan ve fiziksel engelli) sosyal ya da ekonomik sorunlar değil tıbbi sorunlar nedenleriyle ortaya çıktığına kani olmuştu (Carlson, 2011, s. 13; Black, 2003, s. 13). Konu 19. yüzyıl Osmanlısında da benzer bir şekilde tartışılmıştı (Yanıkdağ, 2017). İyi gen anlamına gelen öjeni sağlam soy bilinci olarak düşünülmüş, A.B.D. ve Almanya'da 20. yüzyılda kurumsallaşıp yaygınlaşmış, farklı ülkelerde farklı şekillere bürünmüştü. Negatif öjeni uygun olmadığı düşünülen toplulukları kısırlaştırma, tecrit etme ya da yok etme şeklinde, pozitif öjeni ise uygun kabul edilen toplulukların çoğalmasını sağlamayı hedeflemişti (Yanıkdağ, 2014, s. 268). Öjeni fikrinin Osmanlı ve Türkiye'de yayılmasında Besim Ömer (Akalın) gibi hekimler başı çekiyor (Toprak, 2017b, s. 205), hekimler kendileri de halkın sağlığı ile ilgili antropometriye dayanan küçük araştırmalar yapiyorlardı (Shorter, 2000, s. 117).

Varlığı tehdit altında olan Osmanlı' da dayanışmanın vurgulanması, Ziya Gökalp başta olmak üzere konu ile ilgili kalem oynatanların aileyi dayanışmanın en küçük birimi olarak görmeye başlamasıyla sonuçlanmıştı (Toprak, 2017b, s. 43-44). Bu dönemde Türkiye'de yaşanan kültür krizinin odak noktalarında aile ile beraber kadın ve ahlak bulunuyordu (Duben ve Behar, 2013, s. 213). Dönemin hekimleri konuya dikkati çekiyor, örneğin Doktor Ali Rifat özellikle savaşın başlamasıyla her ülkede "halkın teneffüs ettiği hava-yı ahlakî"nin büyük ölçüde değiştiğini anlatıyor, toplumsal devrimlere ek olarak gıdasızlık ve sıhhi bakımsızlığın verem, frengi, içki gibi "üç büyük afet”"in salgın halini almasından bahsediyordu. Yine de Avrupa'da asıl felaket sebebinin doğum azlı̆̆ olduğu belirtiliyordu (Dr. Ali Rifat, 1933, s. 7). "Bir taraftan evlenmeyi aile teşkilini teşvik, diğer taraftan çocuk ölümü ile mücadeleye atılmak birinci vazifemizdir" diyen Doktor Ali Rifat bunun haricinde memleketin çocuklarını yetiştirecek birer anneye dönüşmesi umulan genç kızlara çocuk bakımı öğretmenin ve verem ve bulaşıcı hastalıklarla mücadele etmenin gereğinin altını çiziyordu (1933, s. 8).

Daha 2. Meşrutiyet'in ilk yıllarında evliliği kolaylaştıran önlemler alınmaya başlanmış, savaş yıllarında gazetelerde izdivaç talepleri yayınlanmıştı. Dolayısıyla Cumhuriyet'in öncesinde de zaten parçalanmaya yüz tutmuş toplumsal düzenin yeniden bir araya getirilebilmesi için önlemler alınmaya başlanmıştı (Toprak, 2017b, s. 56). Nöropsikiyatrlar sağlıklı çiftlerin evlenmelerini sağlamanın dışında bu evlilikleri mümkün mertebe verimli kılmayı da hedefliyordu. Evliliği aşk ya da hayat arkadaşlığı için değil, nüfusu arttırmak için hedeflemek gerekiyordu. Hatta Fahrettin Kerim (Gökay) milli nüfus siyasetinde öjeniyi anlattığı yazısında anne olmayı istemeyen kadınların evlenip de kısıtlı erkek kaynağını harcamaması gerektiğini düşünüyordu. Devlet 1920'lerin sonlarında altı ya da daha fazla çocuğu olan annelere para ödülü ve madalya vermeye başlamıştı (Yanıkdağ, 2014, s. 278-280). 
Türkiye'de de çocuğun bakımı ailevi olmaktan ziyade milli bir mesele olarak görüldüğünden bireylerin kendilerinin ve çocuklarının sağlıklarını korumak milli bir sorumluluk haline gelmekteydi. Bahsedildiği gibi çocuk milli bir davanın kamusal öznesi olarak tanımlandığında onun sağlığından ve selametinden birincil derecede sorumlu olan kişi de daha gebelik öncesinden itibaren (kendisinden potansiyel anne vasfı taşıması beklendiğinden dolayı) annesi olarak tanımlanmaktaydı. Türk kadınlarının çocuk bakım ve yetiştirmesinde fennî ve bilimsel bilgiyi haiz olmalarının önemi dönemin yazılı basınında vurgulanmakta, bu nedenle öncelikle annelerin eğitim düzeylerinin yükseltilmesi gerektiğinin altı çizilmekteydi. Yenidoğan bakımı, özellikle bulaşıcı hastalık endişesinden dolayı anneden başkasının çocuğa yaklaşmamasının telkin edilmesiyle beraber yine annenin görevi olarak tanımlanmaktaydı (Başboğa, 2017, s. 9-13).

\section{Çocuk Sağlığımı Tarihselleştirmek: Erken Cumhuriyet Döneminde Sağlam Çocuk Meselesi ve Sağlık Propagandası}

Hekimlerin yukarıdaki ifadeleri çağdaşları tarafından paylaşılıyordu. Yüzyıl dönümü elitleri modernleşmeyi Batılı olmak ile büyük oranda paralel görmüş ve Batı tarafından benimsenen modern çocukluk imgesini de benimsemişti. Çocuk "kamusal özne olma potansiyeli” taşıyan bir canlı olarak görülmeye başlanmış, böylelikle nüfus siyaseti, vatandaşlık ve milliyetçiliğin kesişim kümesinin ve aynı zamanda ailenin ve toplumun merkezine yerleşmişti. "Çocuk meselesi”, “çocuk davası” gibi ifadelerle anılan konu, pronatalist politikalar, çocuk bakımı ve sağlığı, kimsesiz çocukların sahiplenilmesi, okullaşma gibi sahalarda tezahür etmeye başlamıştı (Çiçek, 2012, s. 76-84).

Çocuk meselesi, Türkiye'de birincisi çocukların anne karnında ya da doğduktan sonra ölmelerinin engellenmesi, ikincisi doğan çocukların da sağlıklı ve uzun ömürlü olmalarının sağlanması olmak üzere iki ana başlıkta ele alınıyordu. Çocuk ölümleri 1skat-1 cenin (çocuk düşürme) ile beraber düşünülüyor ve doğurganlık oranları artırılmaya çalışıyordu. Yaşayan çocukların sağlıklı kılınması ise en az halk sağlığ önlemlerine verildiği kadar eğitime de önem verilerek mümkün kılınmaya çalışılıyor ve sağlıklı olmak medeni olmakla özdeş görülüyordu.

Sosyal sermaye olarak nitelendirilen nüfusa iliş̧in tartışmaların gündeme oturmasının geç 19. yüzyıldan beri gerçekleşen demografik dönüşümlerden kaynaklanan somut bir zemini bulunmaktaydı. Yaşanan kültürel, politik ve teknolojik dönüşümler aileyi çözüyor, kadının konumunu değiştiriyor ve doğurganlık oranlarını düşürüyordu. Duben ve Behar (2013) Türkiye'de doğurganlığın ilk düşüş gösterdiği yer olan İstanbul için yaptıkları hesaplamaları şu ifadelerle özetliyorlardı: “1907'den 1945'e kadarki kırk yıllık zaman diliminde, İstanbul'da doğum oranı üçte birden biraz fazla (\% 36,2), toplam doğurganlık \%37,9 ve evlilikte doğurganlık beşte birden biraz fazla (\% 21,3) düşüş gösterdi” (s. 176). 
Ayrıca yüzyıl dönümünde ortalama kadın evlenme yaşı 20 civarındayken 1930'ların sonunda 23'e yükselmişti. Kadınlar hem giderek daha geç yaşta evleniyor hem de çocuk sahibi olmayı daha erken yaşta bırakıyorlar ve tüm ihtarlara rağmen çeşitli doğum kontrol yöntemlerine sıklıkla başvuruyorlardı (Balsoy, 2015).

Türkiye'nin geçirdiği demografik dönüşümün üç ana aşaması bulunmaktaydı. İlk aşama bu makalenin de konu ettiği dönem olan Osmanlı İmparatorluğu'ndan 1945'lere kadar olan kısımdı ve yüksek doğum ile yüksek ölüm oranları ile belirleniyordu. İkinci aşama 1945 ile 2010'lara kadar olan dönemi kapsıyordu. Bu aşamada ölüm oranlarında hızlı düşüş, doğum oranlarında daha yavaş düşüş gerçekleşmiş ve nüfus hızla artmıştı. Son aşamada ise hem ölüm hem de doğum oranları düşmüştü (Aysan, 2014, s. 67).

İlk demografik değişim döneminin en büyük belirleyicisi savaştı (Shorter, 1985): savaş yıllarında erkekler ya cephede ölmüş ya da verem, tifüs veya frengi gibi hastalıkları kaparak evlerine dönmüşler (Mazhar Osman, 1933, s. 37) ve savaş sonrasında Türkiye'nin nüfus meselesini ilgilendiren en temel konular sitma, trahoma, nekator, verem gibi özellikle yaşam koşulları ile ilişkilendirilen hastalıklar ve başta frengi olmak üzere zührevi hastalıklar haline gelmişti (Kahya ve Erdemir, 2000, s. 322). Milli Mücadele sonunda insanlar savaşın, salgın hastalıkların ve temel ihtiyaçlardan yoksunluğun sıkıntılarını çekmekteydiler (Shorter, 1985, s. 417).

Cumhuriyetin başa çıkması gereken sorunlar arasında Osmanlı'dan kalan ekonomik ve sosyal sorunların yanı sıra üretken ve sağlıklı bir nüfus oluşturma çabasının arka planındaki zorluklar vardı. Doğum ve ölüm oranlarının dengelenmesinin getirdiği zorluğun haricinde nüfusun \% 80'inin kırsalda yaşıyor olması ve emek yoğun tarım yapısına dayanan sistemde genç erkek sayısının haneler ve devlet için zenginlik kaynağı olması, pronatalist düzenlemelerin ülkenin nüfus politikasının temelini oluşturması sonucunu doğurmuştu (Aysan, 2014, s. 74-75).

1 Kasım 1925 ve 1926 Meclis açılış konuşmalarında Mustafa Kemal salgın hastalıklarla mücadelenin ve sağlıklı, genç ve üretken bir nesil ortaya koymanın önemini anlatıyordu (Erdal, 2011, s. 784). Maarif Vekâleti, Çocuk Esirgeme Kurumu, Halkevleri salgın hastalıklarla mücadele konusunda özellikle çocuklara yönelik ya da çocukların korunması konusunda yetişkinlere yönelik pek çok yayın yapmaktaydı. İstanbul Verem Mücadelesi Cemiyeti'nin kurucularından olan Doktor Tevfik Salim (Sağlam) nüfus sorununu bir ülkenin en önemli sermayesinin insan sermayesi olduğunu ve Türkiye'de topraklara göre nüfusun az olduğunu, nüfusun çoğaltılması ve ömürlerin uzatılması için çalışmanın her Türk'ün baş görevi olduğunu söyleyerek anlatıyordu. Bu görevde başarılı olabilmek için birkaç kişinin çalışması yeterli değildi, tüm milletin gayret etmesi gerekiyordu (1929, s. 2-3). Nüfus yoğunluğunun düşüklüğü, dönemin en önemli meselesi olarak algılanmakta ve konu ile "medeni memleketlerin" yakından ilgilendiği vurgulanmaktaydı (Dr. Ali Rifat, 1933, s. 6). 
Gerçekten de konu tüm Avrupa'nın gündemindeydi ve Türkiye'de nüfus meselesiyle ilgilenen herkes Avrupa'daki tartışmaları takip etmekteydi. Boverat'1n (1932) sosyolog ve iktisatçılardan oluşan “Avrupa Nüfusunun İstikbali 1931 Roma Beynelmilel Nüfus Kongresi” ve Marshal'ın (1932) “Kanunların Nüfus İnkişafina Tesirleri” eserleri çevrilerek yayımlanmıştı. 1934'te Charles Balas’nın “Nüfus İşlerinde Nereye Gidiliyor?” eseri İstatistik Umum Müdürlüğü tarafından tercüme edilmişti. Bahsedilen ve benzeri eserleri takip eden aydınlar da nüfus konusunda pek çok yayın yapmıştı (Erdal, 2011, s. 782). Ülkü Mecmuası'nda Dr. Zeki Nasır, Nusret Kemal, Fahrettin Kerim Gökay, Necip Ali Küçüka gibi isimler pronatalist politikalardan öjeniye uzanan bir çizgide yazılar yayımlamıştı (Erdal, 2011, s. 785). La Turquie Kemaliste gazetesi vasıtasıyla arzu edilen nesillerin yetiştirilmeye başlandığının tüm dünyaya duyurulması hedefleniyordu (Okumuş, 2017).

Çocuk himayesinin Amerika ve tüm Avrupa' da milli bir ülkü olduğu ifade ediliyor, amaç doğumu arttırmak ve ölümü azaltmak yoluyla "hikemî ve ruhî sıhhatli bir halk kitlesi yaratmak" olarak tanımlanıyordu. Bu amaca giden esas yol bilimdi. Biotechnie (yaşamak ilmi) olarak tercüme ediliyor ve eugénetique (iyi genetik) ile puériculture (çocuk bakımı)'ün, aynı zamanda sosyoloji, içtimai ahlak ve zootéchnie gibi alanların isimleri zikrediliyordu. Bu bilimlere göre bir insanın ortaya çıkışı tesadüfi olmamalı, bilakis ebeveyn adaylarının bedenî, aklî ve ruhî sağlıkları yerinde olmalıydı. Bu süreçte anneler himaye edilmeden çocuğun himaye edilmesi mümkün değildi. İçtimai bir sermaye olan nüfusun çoğaltılması aynı zamanda iktisadi bir işti (Dr. Kudsi, 1934, s. 2). Dolayısıyla nüfus ve çocuk söz konusu olduğunda müspet, sosyal ve beşeri bilimler bir arada uygulanmalıydı. Bilimdışılık, safsata ve hile anlamına geliyordu. Şarlatanlıkla mücadele de Himaye-i Etfal'in görevi olarak addediliyordu.

Çocuk sağlığı açısından tehlike teşkil eden ve gündemin merkezine alınan üç ana sorun bulunmaktaydı: Salgın hastalıklar, 1skat-1 cenin ve genel olarak çocuk ölümleri. Aynı zamanda memleketin hayatta kalan çocuklarının güçlendirilmesi ve sağlığa kavuşturulması isteniyordu. Çocuk ölümlerinin bir milli mesele haline gelmesi modernleşmenin getirdiği bir değişimdi. Armstrong’un (1986) iddiası, istatistiksel olarak takip edilen "çocuk ölümleri" kavramının da belirli bir düşünme biçiminin ürünü olduğuydu. 19. Yüzyıl sonunda sosyal hijyen teknolojisi çocuğu tıbbi ilginin odağına koyuyordu. Özellikle çocuğun "bedeni” artık hekimlerin dikkatini çekmekteydi (Hendrick, 1997, s. 13). Yeni istatistikler, idari dertlerin bir ürünüydü ve hanelere müdahale edilmek suretiyle sağlık uygulamalarının geliştirilmesine yarıyordu. Dolayısıyla Armstrong “çocuk”un ve özellikle "çocuğun bedeni"nin bir medikososyal sorun olarak inşa edildiğini söylüyor, böylelikle hane içi ve ailevi özel alanlara müdahaleye kapı araladığını ifade ediyordu (James, Jenks ve ark., 2007, s. 151-152). 
Tüm bunların önünü almak için belirli politikalar geliştirilmiş fakat bu politikaların uygulamaya konup yaygınlaştırılması hem uzun zaman alacağından hem de sağlık alanının bütünüyle devlet tarafından üstlenilmesi için yeterli bütçe olmadığından sorumluluk bireyler ve çeşitli cemiyetlere dağıtılmıştı. Bunun sonucunda dönemin hekim ve bürokratlarının belirlediği sağlık önlemlerinin alınabilmesi için her şeyden evvel propagandaya önem verilmişti. Propagandanın "içtimaî, fennî ve amelî bir surette ve tam bir ihtisas dairesinde" olması gerekiyordu (Gökçe, 1957, s. 45). Dar bütçelerle sağlık önlemleri alınmaya çalışılırken memleketinin selameti için kendisinin ve başkalarının sağlığını koruma görevinin bireyin sorumluluğu olarak tanımlanmasının bir örneği, ülkenin çeşitli illerinde hazırlanan tıbbi topografyalarda görülmekteydi. Yine de propaganda ve eğitimin önemini vurgularken Türkiye'ye has ekonomik dertlerin önemini yeniden düşünmek gerekmektedir. Aynı dönemde cehaletin veremle mücadelede ilk kurtulunması gereken şey olduğu düşüncesi Kanada'dan Meksika'ya dünyanın pek çok yerinde ifade edilmekte olup özellikle kadınların sorumluluğu vurgulanmaktaydı (Sears, 1992, s. 74; Stern, 1999).

Hekimlerin çocuk sağlığı ile ilgili bu derece endişeli olmaları ve her vesile ile telkinlerde bulunmalarının altında yatan sebeplerinden biri geç 19. yüzyıl- erken 20. yüzyıl döneminde halk sağlığında sanitasyondan ${ }^{2}$ hijyene doğru yaşanan dönüşümdü. Bu geçiş iki temel seviyede gerçekleşmişti: Uygulamada halk sağlığı müdahaleleri fiziksel çevrenin sıhhi durumundan evlerdeki hijyenik standartlara yönelmişti. Bu durumun teorideki karşıllığ ise ikinci seviyeyi oluşturuyordu: Halk sağlı̆ı̆ uygulamaları mikrop teorisinin kabulünü cisimleştirmişti (Sears, 1992, s. 69). Sihhi bilim nüfusu oluşturan bedenleri dış çevrelerinden ayıran anonim bir sınır üzerine odaklanmıştı. Kişisel hijyen ise her biri farklı alışkanlıkları tanımlayan sayısız bireyselliği tanımaya başlamıştı (Armstrong, 1993, s. 401). Hijyen bu şekilde tanımlandığında, tıbbi bilgi artık sinırları belli olmayan bir zeminde hareket edebiliyordu.

T1bbi bilginin müdahale edebilmesini mümkün kılan şey ise topluma ilişkin edinebileceği bilgiydi. 1922-1938 yılları arasında yayımlanmış olan Türkiye'nin Sıhhi ve İçtimai Coğrafyası 19 eserden oluşan bir diziydi ve ülkenin sağlık sorunlarını çözümü için bir keşif çalışması niteliğindeydi. Bu eserlere göre örneğin veremin temel sebepleri arasında hijyen konusundaki bilgi eksikliğinden kaynaklanan hatalı davranışlar, sıhhi olmayan örf ve adetler ya da temiz hava ve su kadar yoksulluk, göç, sefalet, kötü çalışma koşulları, gıdasızlık, yaşam koşulları gibi sosyal unsurlar da sayılmış, hatta Kastamonu raporunda sıhhi mücadeleden ziyade Maarif ve İktisat Vekâletlerinin mücadele etmesi önerilmişti (Tanış, 2019). Aslında raporlar sosyal ve ekonomik koşullara işaret ediyordu; fakat alınan önlemler tıbbi olmuştu. Ülkede bütçe olmaması ve geniş yayılımlı iktisadi önlemler

2 Temiz su ve atık su ile atık bertarafı gibi halk sağlığını korumak için tasarlanmış prosedür ve önlemlerin incelenmesi ve uygulanmasi. 
kısıtlı olmasından dolayı söylem ve vatandaşlık meselesi gündeme gelip sağlıklı olmak bireyin sorumluluğu olarak düşünülecekti.

Çocuk düşürmek ülke için ayrı bir sorun olarak görülüyor, kadınların bunu yapması engellenemiyordu. Konu hem ahlaki hem de demografik açılardan ele alınıyor, kadınları çocuk düşürmeye iten sebepler aranıyordu. 1926 yılında Doktor Cemal Zeki’nin kaleme almış olduğu “Çocuk Düşürmek Esbâbı, Tehlike ve Kıbetleri ve Buna Mani Olabilecek Tedâbir" başlıklı bir kitap yayımlamıştı. İki bölümden oluşan bu kitabın bir kısmı halka, bir kısmı da hekimlere yönelik olarak kaleme alınmıştı ve nihayetinde bu kitap da çocuk düşürmenin "ülke kadınlığını kemiren toplumsal bir facia” olduğunu ve "ülke nüfusunu çökerttiğini” yazıyordu (Toprak, 2017a, s. 53). Oysaki çocuklar onları yetiştirenlerin değil, tüm ülkenindi, dolayısıyla çocuk düşürmenin önüne geçmek elzemdi (Doktor M. Talat Özkan, 1935, s. 18-19). Dolayısıyla çocuk sağlıklı bir biçimde büyütülüp ulusa armağan ediliyordu.

Resimli Ay dergisi bu konu için 1927 senesinde bir anket yayınlamış ve üç hekim ile bir ebeye çocuk doğum, ölüm ve düşürülmesi ile ilgili çeşitli sorular sormuştu. Hekimler Kadri Raşit, İhsan Hilmi ve ülkenin ilk kadın doktoru olan Safiye Ali, ebe de Kadriye Hanım isminde biriydi. Katılımcılara çocuk ölümlerinin oranı, ülkede bilimsel çocuk bakımını bilen ve uygulayan ailelerin oranı, kadınlar arasında çocuk düşürme eğilimi, çocuk düşürmek isteyen kadınların uyguladığı bilimdışı yöntemler gibi konulara ilişkin sorular sorulmuş ve kişisel deneyimlere dayanan cevaplar alınmış, böylelikle konuyla ilgili endişeler dile getirilmişti (Toprak, 2017a).

Cemal Zeki'nin kaleminden çıkmış olanlara benzer ifadeler 1920 ve 1930'lu yılların basınında sıklıkla yer almaktaydı. Çocuk düşüren kadınların aslında bireysel değil, toplumsal anlamda sorumluluklarını üstlenmedikleri, bilakis kendilerine ve topluma zarar verdikleri iddia ediliyordu. Çocuk düşürmenin amili olan sebepler hastalıklara ve toplumsal sebeplere bağlı olmak üzere ikiye ayrılıyor, hastalıklarda öncelikle frengiye değiniliyordu. Toplumsal sebepler sefahat düşkünlüğü, alkol ve keyif verici maddeler gibi sebepler olarak görülüyor, çocuk düşürmenin her sınıftan kadın arasında görüldüğünün altı çiziliyordu. Fakir ve orta halli ailelerde ihtiyaç, eşi tarafından darp edilmek gibi sebepler öne sürülürken zengin ailelerin keyif düşkünlüğünden çocuk düşürdüğü ifade ediliyordu (Dr. Ali Rifat, 1933, s. 9).

Dr. Tevfik Remzi, çağdaşı pek çok hekime kıyasla farklı bir noktaya vurgu yapıyor, kadınların mevcut düzende desteksiz kaldıklarını ifade ederek çocuk sahibi olma(ma)k konusundaki haklarını dile getiriyordu. Kadınlar muayenehaneye geldiklerinde dahi çocuklarını kazara mı kasten mi düşürdüklerini söylemiyorlardı. Tevfik Remzi'nin tahminine göre, yokluk ve gayrimeşru çocuk sahibi olmak birincil amillerdi. Böyle bir durumda olup çocuk düşürmeye çalışan kadınlar için bir hastane yapılmalı ve isimleri anonimleştirilmek kaydıyla hem doğum yapmak hem de doğumdan sonra çocuklarını 
terk edip gitmek özgürlüklerine sahip olmalıydılar (Doktorlarımıza Göre Doğumlar ve Çocuk Ölümleri, 1935, s. 24).

Dr. Kadri Raşid de Tevfik Remzi gibi kadının üzerinden tanımlanan çocuk yetiştirme sorumluluğunun arkasında destekleyici bir yapı olmadığını anlatıyordu. Çocuğu büyütenin esas olarak anne olduğunu ama eşi de dâhil olmak üzere herhangi bir destek almadığını ve memlekette çocuk ölümleri meselesinin sadece hayır cemiyetleriyle çözülemeyeceğini söylüyor, bu bakımdan vatandaşları hayırsever cemiyetlere desteğe çağıran çağdaşlarından ayrı düşüyordu. Hasta çocuklar ücretsiz olarak bakılıyor olsa da anneleri yazılan reçeteleri yaptıracak maddi imkânlardan yoksundular, üstelik tüm ülkede çocuklara mahsus sadece Şişli Etfal Hastanesi bulunmaktaydı (Doktorlarımıza Göre Doğumlar ve Çocuk Ölümleri, 1935, s. 27-28).

Çocuk ölümleriyle mücadele etmenin bir yöntemi öncelikle kadınlar olmak üzere halkı eğitmekse, diğer yolu kadın ve çocuk sağlığı alanlarını profesyonellere teslim etmekti. 1843 yılında Fenn-i Kıbale kurslarının açılmasıyla başlayan bu çaba, 1892'de Viladethane'nin açılmasıyla beraber doğumların modern tıbbın gereklerine göre yapılmasının bir norm haline gelmesine dönüşmüştü. Besim Ömer' in kadın ve çocuk sağlığı alanındaki öncü faaliyetleri, ülkenin ilk kadın doktoru Safiye Ali’nin öncülüğü ile kadın doğum alanı modern tıbbın konusu haline gelmişti (Okay, 1998, s. 58). Hastalanan çocukları doktora götürmek ise 19. yüzyıl ebeveynleri için başlı başına büyük bir yenilikti. Zaman içinde ihtisaslaşmanın yaygınlaşmasıyla beraber bu alışkanlık hastalanan çocuğu her doktora değil çocuk doktoruna götürmeye dönüşmüştü. Çocuk doktoru ve çocuk ilaçları ilanlarının yoğunluğu bu saptamayı destekler kuvvetteydi (Okay, 1998, s. 62).

Doğan çocukların ölmesinin sebepleri ise savaşın bıraktığı bakımsızlık, sefalet, toplumsal yaralar, hıfzıssıhhaya riayetsizlik, zayıf doğum, hazım fesatları, uygunsuz beslenme, frengi gibi hastalıklar, cehalet ve sarhoşluk, temiz havadan yoksunluk idi (Dr. Ali Rifat, 1933, s. 8-11). Çocuk Esirgeme Kurumu'ndan alınan verilerin ışığında hekimlerin "ulusun çocuğu" hakkında yaptıkları çıkarım, çocukların özellikle ilk aylarda bakımsız kalmasının ölümlere sebebiyet veriyor olduğuydu (Ulusun Çocuğu, 1935, s. 13-16).

Çocuk ölümlerine karşı annelerin "teknik" yetiştirilmesi için hekimler hem birbirlerine telkinlerde bulunuyor hem de her firsatta anneleri bilgilendiriyorlardı. $\mathrm{Bu}$ görev çocuk hekimleri, çocuk yetiştiren mütehassıs tabipler ve ziyaretçi hemşirelere düşüyordu. Uygulamalı derslerin yapılması için annelerin önceden teorik eğitime tabi tutulması öneriliyor; okullarda çocuk yetiştirme konusunda kitaplar ve risaleler bulundurulması ve bütün çocuklara ücretsiz olarak ulaştırılması isteniyordu. Günlük gazetelerde herkesin anlayabileceği bir dilde yazılar yazılmalı, hatta haftanın belli günlerinde bu konuya birer sütun ayrılmalıydı. Ayrıca anaokulları ve ilkokullarda tıbbi 
muayenenin ötesine geçilmeli, tüm çocuklar için birer sağlık dosyası tutulmalı ve dersler çocukların hava almalarına müsaade edecek şekilde planlanmalıydı (Doktor Talat Özkan, 1934, s. 7-8).

Çocuklarının iyileştirilmesi ve güçlendirilmesi, bazı pilot uygulamaları beraberinde getirmişti ve beden terbiyesi bunun önemli bir parçasıydı (Akın, 2014). Bu uygulamalardan bir tanesi, azat obalarıydı. Okulların azat, yani tatil oldukları dönemde kurulan bu sağlık kamplarının fikir babası Trakya Umumi Müfettişi Kazım Dirlik’ti. Uygulamayı Avrupa'daki örneklerinden gören Dirlik, 1935 yılında İzmir Valiliği döneminde "Çocuk yurtları" ismiyle bu uygulamayı başlatmış ve Trakya Umumi Müfettişliği'ne atandığında burada da ilgili çalışmaları başlatmıştı. Tasarı, Trakya'nın tatil alanlarında, yayla ve plajlarında 20 azat obası açarak bulaşıcı hastalıklar haricinde kalan hasta ve cılız çocukları yeme-içme ve giyim gibi ihtiyaçlarını da karşılamak suretiyle iki aylığına kampa almak yönündeydi (Burgaç, 2011, s. 655-656).

Obalara kabul edilecek çocuklar hükümet ya da belediye hekimleri tarafindan yapılan muayene sonucunda belirlenecekti. Obaların temel hedefinin çocukları gürbüz hale getirmek olmasından dolayı öncelik gıdaya verilmiş, çocuklar için örnek yemek çizelgeleri ve verilecek gida miktarları belirlenmişti. 1936' daki bu ilk deneme sonunda çocuklar ortalama iki ila altı kilo almışlar ve bu başarının ardından çalışmalar devam etmiş, sonuçta 1938 yılına kadar hedeflenen 20 obanın 14’ü açılmış, toplam 463 çocuk kabul edilebilmişti (Burgaç, 2011, s. 657-662).

\section{"Sıhhatler Diyarı"na Davet: Verem, Çocuk Sağlığı ve "Çocuk Sahifeleri”}

Erken Cumhuriyet döneminde sadece çocukların değil, herkesin sağlığını etkileyen önemli hastalıklardan biri veremdi (İlikan Rasimoğlu, 2012; İlikan Rasimoğlu, 2018). 1901-1923 istatistiklerine göre İstanbul'da veremden yılda ortalama 2.800 kişi ölüyordu. Bu sayının tüm ölümlerin \% 15,8'i olduğu ifade ediliyordu. Besim Ömer de 1918 tarihli Verem Tehlikesi ve Veremle Mücadele'de İstanbul'da veremden ölenlerin oranını \% 10,8 olarak vermekteydi (Tuğluoğlu, 2008, s. 5).

Sihhat ve İctimai Muavenet Vekâleti 1938 yılında verem üzerine bilgilendirici bir risale yayımlamıştı. Bu risalede tedavinin 6 aydan 4 yıla kadar sürdüğü, diğer bulaşıcı hastalıklar gibi hızlı iyileşmediği için hastaların tedavi planlarını bozmalarının veremle mücadelenin önünü aldığını anlatmıştı. Tedavi istirahat, açık hava, güneşten faydalanma ve sıhhi beslenmeden oluşuyordu. Esas önemli olan risalenin sonuna büyük harflerle eklenen ibarelerin arasında şu ifadelerin de bulunmasıydı: "Yurdunu ve yurttaşını tehdit eden bu içtimaî afetten sakın ve kork." (Verem (Tüberküloz), 1938, s. 8). Bu ifade iki konuyu gözler önüne sermektedir. Birincisi, sağlığı korumanın bireyin değil toplumun meselesi olduğu fikri yayılarak toplumun iyiliğinin öncelenmesine yönelik anlayışa katkıda bulunmaktadır. İkincisi, hastalığın mikrop teorisi ve onunla beraber 
gelen Pasteur Devrimi'nin bireylerin hastalık algısı ve gündelik hayatında yapması gereken değişikliğin biyopolitikanın alanına girdiğini göstermektedir.

Bu etiyoloji ${ }^{3}$ iki dünya savaşı arası döneme hâkim olmuş, dolayısıyla alınması tavsiye edilen önlemler ve tedavi yöntemleri değişmemişti. Mikrop teorisi toplumlar için henüz yeni olduğundan tıp henüz mikroplar karşısında savunmasızdı fakat helyoterapi ${ }^{4}$ gibi "hijyen" kategorisine giren önlemlere her zaman başvurulabilirdi (Carter, 2012, s. 94). Verem mücadelesinde sanatoryum uygulaması dünyanın pek çok yerinde hayırseverler, belediyeler, dini kurumlar ve devletin ortak çabalarıyla gerçekleşebilmişti. 1891'de Fransa'da ilk örneği görülmüş olan ulusal veremle mücadele cemiyetleri 20 yıl içerisinde Avustralya'dan Japonya'ya kadar yayılmış ve veremle mücadele büyük bir hayırseverlik işi haline gelmişti. 1904'te Danimarka'da başlayan ve 1911'de bir sanatoryumun inşasını sağlayan verem pulları satışı uygulaması da aynı hızla yayılma göstermişti (Bynum, 2012, s.131-132).

Başta Besim Ömer Akalın'ın katıldığı, hakkındaki görüşlerini yayınlamış olduğu ve 7-17 Mayıs 1912'de Washington'da toplanmış olan Dokuzuncu Uluslararası Kızılhaç Konferansı olmak üzere pek çok uluslararası kongreye katılmış olan hekimler; veremle mücadelede gönüllüğün, dispanser ve sanatoryumların ne kadar etkili olduğunu görmüştü (Düzcü ve Sezer, 2016). Bunun üzerine benzerlerinin Türkiye'de de kurulması için çalışmaya başlamışlardı. 20 Nisan 1918'de Besim Ömer'in öncülüğünde Verem ile Mücadele Osmanlı Cemiyeti kurulmuş, onu Behçet Salih (Uz)'un başkanlığında 18 Şubat 1923'te İzmir Veremle Mücadele Cemiyeti izlemiş, 2 Ekim 1923'te Balıkesir'de üçüncü cemiyet kurulduktan sonra dördüncü olarak 1927 senesinde İstanbul Veremle Mücadele Cemiyeti kurulmuştu (İlikan Rasimoğlu, 2012).

Kamu kaynağı ve cemiyet bütçelerinin kısıtlı olmasına rağmen daha 1923 yılında dispanserler kurulmaya başlanmış (Yıldırım, 2010), s. 97), 1929 senesinde ülkenin ilk büyük dispanseri açılmıştır. Verem dispanserlerinde sadece veremliler tedavi edilmiyor, aynı zamanda vereme neden olan faktörler belirlenip önlemler alınmasına çalışılmıştır (Tekir, 2019, s. 418). Dispanserler kentlerin dışında verem mücadelesinin verileceği mekânlar olduğundan cemiyet bu konuya ağırlık veriyor fakat eğitimi tedaviden öncelikli k1lıyor, yönetimin her kademesindeki çalışanların işbirliği içinde çalışmasının önemi vurgulanıyordu. Verem hastalığı ancak hükümetin cömert, belediyelerin uyumlu olduğu; toplumsal eğitimde itaatkârlık ve genel bir gayretkarlık olduğu takdirde yenilebilirdi (Gökçe, 1969). 1924-1932 yılları arasında 85 verem yataklı Haydarpaşa ve 35 verem yataklı İzmir Emraz-1 Sâriye Hastanelerinde tedavi edilen hastaların

3 Tibbi terminolojide hastalıkların nedenlerinin incelenmesi anlamda kullanılmaktadır.

4 Güneşle tedavidir. Bu tedavi biçimi 19. yüzyılın sonundan itibaren, uzun süre güneş ışı̆̆ına maruz kalmanın bakterileri öldürebileceği düşüncesiyle özellikle kemik, eklem ve cilt tüberkülozunun tedavisinin önemli bir parçası haline gelmişti. Açık havanın temini ve D vitamini seviyesinin yükseltilmesini sağladığı için özellikle çocukların tedavisi için sıklıkla başvurulan bir yöntemdi. 
toplam sayısı 8.110; çekilen toplam röntgen sayısı 42.383’tü. Aynı yıllar arasında Heybeliada Sanatoryumu'nda toplamda 1.110 kişi yatarak, 12 kişi ayakta tedavi edilmişti (Aksu, 2007, s. 83-84). Erenköy Sanatoryumu’nun kuruluş ve idamesinde İstanbul Verem Savaş Derneği'nin bütçesinin sarsılmaması için bağışlara ağırlık verildiği (Demir, 2019, s. 24) düşünüldüğünde tedaviden ziyade neden eğitime öncelik verildiği daha iyi gözükmektedir.

"Sıhhatimi Verem Mücadele Cemiyeti Kurtardı" (Yaşamak Yolu, 1934, s. 1-3) gibi başlıklarla dispanserde iyileşen veremli baba hikâyeleri anlatılıyor, cemiyetin önemi vurgulanıyor, dispanser ve ziyaretçi hemşirelerin faaliyetlerinin faydaları hatırlatılıyordu (Uludağ, 1934, s. 1-3). Bu dispanserlerin masrafları dergi abonelikleri, pullar, bağışlar ve benzeri yollarla finanse edildiğinden, abonelik ve yardım konusunda teşvik edici mesajlar içeren ifadeler özellikle 1933 yılından itibaren yetişkinlere ve çocuklara yönelik kaleme alınmış yazılarda sıklıkla yer alıyordu.

“Sağlık Türeleri” başlığıyla sağlık öğütlerini özetleyen bir tür and dahi yazılmıştı. $\mathrm{Bu}$ andı söyleyen kişinin şu eylemleri gerçekleştireceğini taahhüt etmiş olduğu varsayılıyordu: temiz hava teneffüs etmek, açık havada bulunmak, açık pencereli odada yatmak, burundan nefes almak, haftada en az bir kere y1kanmak, elbiseleri temiz tutmak, okulda daima dik durmak, sınıfı ve evi kirletmemek, yatmadan önce dişleri firçalamak, yere tükürmemek, tükürük bulunması ihtimali olan şeyleri ağza götürmemek ve yemeklerden önce, sonra ve lavabodan çıktıktan sonra elleri yıkamak (Yaşamak Yolu, 1935, s. 6).

19. yüzyılın sonunda çocuklarda verem pek çok ülkede başı başına bir sorun haline gelmişti. Bu dönemde verem yoksulluk ve sağlıksız yaşam koşulları ile ilişkilendirilirken artık başkalarının bedenleri ile ilişkilendiriliyordu (Armstrong, 1993, s. 404). Mikrop teorisinin getirdiği bilgi çocuklardaki zafiyet, hasta eklem ve bağırsak ve çeşitli enfeksiyonları açığa kavuşturmuş ve özellikle Sosyal Darvinistler'i hastalıkları yeni kuşaklara geçirip ırkın zayıflamasına sebebiyet vermeleri korkusu sarmıştı. Bu kaygılar ordu ve sanayi için gerekli olan nüfus ile bir tutulan nüfusla ilgili giderek artan endişelerle birleşince ortaya bir dejenerasyon korkusu çıkmış ve çözüm 1rk hijyeninde görülmeye başlanmıştı (Bynum, 2012, s.160).

Rejimin geleceğinin teminatı olarak görülmeye başlanan çocuğun sadece gürbüz ve sağlıklı olması değil aynı zamanda ülkenin gereklerine uygun şekilde eğitilmesi Cumhuriyet elitlerinin temel davalarından biri haline gelmişti. Çocuğun eğitiminin rejimin teminatı oluşu onun her vesile ile vatandaşlık eğitimine de tabi tutulmasıyla sonuçlanıyor ve ders kitapları vatan sevgisi ile memleketin değerlerine ve önceliklerine yönelik ihtimamı gösteriyor, bu bağlamda çocuğun sağlığını içeren yazılara da sıklıkla rastlanıyordu (Şirin, 2013, s. 1277-1278). 
Çocuk bakımının tarihi Antik Mısır'a, ilk tıp yazmalarından olan Ebers Papirüsüne kadar götürülüyor ve 20. yüzyıla gelindiğinde "etfal ilmi”nin “modern” bir tarza bürünüp çeşitli dallara ayrıldığı söyleniyordu. "Doğduğu vakit 50 santim boyunda ve ancak 3 kilo ağırlığında olan bu canlı diğer canlılara kıyasla geride doğduğundan" topluma o çocuğun büyümesi için doğar doğmaz credé manevras $1^{5}$ yapmak, B.C.G. ve çiçek aşısı, süt, bahçelerde oyun alanı, kardeşleri hasta olunca onlardan ayırmak, okulda diş muayenesi, çorba içirmek, tatillerde seyahate çıkarmak, kampa götürmek" gibi görevler biçilmekteydi ve puerikültürün ${ }^{6}$ önemi vurgulanmaktaydı (Prof. Dr. İhsan Hilmi, 1934, s. 1).

Cumhuriyet ile beraber tüm vatandaşlar "müstakbel birer öğrenci" haline gelmiş̧i. Cumhuriyet elitleri için rejim bir medeniyet projesiydi. Dolayısıyla medenileşmesi gereken çocuklar, nitel ve nicel açıdan millete layık duruma gelecek, millete hizmet edebilecek donanıma sahip olacaklardı. Davranış kuralları ders kitaplarında, basında, temsillerde, olabilecek her yerde karşılarına çıkıyordu (Öztan, 2012, s. 68). Hijyen ve medeni davranış kalıpları konuşulduğunda, yetişkin öğrencilere ulaşmanın bir yolunun da çocuklardan geçtiği düşünülebilir. Elbette çocuklar aracıllğıyla aktarılan sağlık bilgilerinin ne kadarının yetişkinlerin gündelik pratiklerine yansıdığını kestirmek güçtür (Öztan, 2012, s. 64). Ebeveynler y1llar sonra kendilerine sorulduğunda çocuk yetiştirmenin onlar tarafından toplumsaldan ziyade bireysel olarak algılandığını ifade etmekteydiler. Ayrıca terbiye-i etfal konusunda babalara yönelik yaygın bir literatür de bulunmaktaydı (Duben ve Behar, 2013, s. 245). Yine de söylemlere bakıldığında esas sorumluluğun annelerde olduğu varsayımı görülmekteydi.

Nobert Elias uygarlaşma incelemesinde Ortaçağ'dan itibaren toplumların görgü kurallarını incelemiş ve 19. yüzyıla kadar hijyene ilişkin davranışların görgü kurallarını meşru kıldığı durumlara rastlamamıştı; fakat bu tarihte tıbbın sağlıklı kabul ettiği davranışlara Batı ülkelerinde üst orta sınıflar tarafından sıklıkla başvurulmaktaydı. Diğer bir ifadeyle, tükürmekten kaçınma durumunda olduğu gibi tıbbi bilgiye dayanan hijyen normları elit grupların bu davranışları benimsemelerine sebep olmamıştı fakat bu davranışlara fazladan meşruiyet kazandırmıştı (Pinell, 1996, s. 2-7). Türkiye'de de tıbbi bilgiyle meşrulaşan üst ve üst orta sınıf davranış kalıpları, görgü kuralları haline gelmişti.

Görgü kurallarına ilişkin bilgiler Türkiye'de de dönemin basınında önemli yer tutuyor, çocukların bu kuralları öğrenmeleri hayati olarak görülüyor, aynı zamanda telkin edilen davranışlar arasında sağlığa ilişkin olanlar sıklıkla yer alıyordu. Temizlik, "bir medeniyet şartı" olarak sunulmuştu (Öztan, 2012, s. 143). Öksürük ve burun silme alışkanlıkları birer adap bilgisi olarak tanımlanıyor ve bu yolla hem tahayyül edilen vatandaş biçimine ulaşmak hem de bulaşıcı hastalıklardan kaçınmak hedefleniyordu (Başboğa Özen, 2019, s. 66).

5 Yenidoğanda göz enfeksiyonunun gelişmesini engellemek için göze gümüş nitrat uygulanması yöntemi.
6 Çocuğun ruhsal ve bedensel gelişimi ile ilgilenen tıp dalı. 
Cumhuriyetin kurucu kadroları sokağı modernleşmenin vitrinlerinden biri olarak kurguladıkları ve sokakların temizliğinin aynı zamanda medeni bir toplumu simgelediğini düşündüklerinden, tasarlanan yeri toplumun bireylerinin sokakta nasıl bulunması gerektiğine dair ayrıntılı tanımlamalar yapıyorlardı. Başta verem olmak üzere bulaşıcı hastalıkların yaygınlığı, sokağa tükürme konusunun daha detaylı şekilde ele alınmasını beraberinde getiriyor; yeme içme ve sofra görgüsü ile sağlıklı beslenme ve hijyen konusunda telkinler birbirleriyle örtüşür duruma geliyor; yemekten önce ellerin sabunla yıkanması, sonrasında ise ağzın yıkanması ve dişlerin fırçalanması telkin ediliyordu. Çocuğun giyinme adabı da sağlık çerçevesinde değerlendiriliyor; giysilerin pamuktan mamul, temiz ve iklime uygun olmasının önemi vurgulanıyordu (Başboğa Özen, 2019, s. 69-79).

Yine de çocuklarda veremin görülmesinin hekimler tarafından engellenmeye çalışılmasının tamamen biyomedikal paradigma ile açıklanabilecek boyutları da vardı. Her şeyden önce primer tüberkülozlu çocukların hastalığın veremin başka formlarına, özellikle tüberküloz menenjite maruziyeti artıyordu. Ayrıca süt tüketimleri yetişkinlere kıyasla çok fazla olduğundan sığır tüberkülozuna yakalanma ihtimalleri yüksekti. Bunların haricinde yetişkinlerle aynı temel yoldan, yani solunum yoluyla hastalığı alıyorlard1 (Bynum, 2012, s. xviii).

Dr. Süleyman Edhem vereme karşı en savunmasız grubu teşkil eden çocukların veremden korunmasının veremle mücadelenin en önemli adımı olduğunu anlatıyordu. Bunun için Fransa' da uygulanan Grancher ${ }^{7}$ yöntemini anlatıyor ve yöntemin Türkiye'de de uygulanmasını tavsiye ediyordu. Grancher yöntemine göre 3 ila 5 yaşları arasındaki hasta çocuklar evlerinden çıkarılarak köydeki sağlıklı ailelere gerekirse 13 yaşlarına kadar bakılmak üzere veriliyor, ziyaretçi hastabakıcılar senede birkaç defa bu çocukları ziyaret ediyor ve durumların değerlendiriyordu. Bu arada öksüz kalan çocuk olursa yanında bulunduğu aile ya da bir başka aile tarafından evlatlık olarak alınıyordu. Süleyman Edhem bu yöntemin Fransa'da 25 yıldır başarılı bir şekilde uygulandığını ifade ediyordu (1929, s. 5).

Tüberküloz basili bulaş yollarını kalabalık ortamlarda daha rahat bulduğundan, okul çocukları daha büyük tehlike altındaydı. İstanbul Verem Mücadele Cemiyeti kurucularından Tevfik İsmail (Gökçe) okul, tezgâh, fabrika gibi nüfusun yoğunlaştı̆̆ alanlarda çocukların verem tehlikesine maruziyetlerinin arttığının altını çizerek

7 Jacques-Joseph Grancher (1843-1907). 1903’te “L'œuvre Grancher” olarak bilinen çocukların tüberküloza karşı koruma çalışmalarını kurmuş olan çocuk hekimidir. Bahsi edilen yöntem ailenin taşraya taşınmasıını öngören klasik hasta bakımı anlayışı ile yüzyıl başının yeni Pastöryen bilimsel bakışını birleştirmişti. Pierre Vayre, Professeur Joseph Grancher (1843-1907). Centième Anniversaire de la mort d'un pasteurien convaincu. http://www.academie-medecine.fr/professeur-joseph-grancher-1843-1907-centieme-anniversaire-de-lamort-dun-pasteurien-convaincu-2/ Erişim tarihi: 25.09.2019. Grancher'in modeli veremli hamile kadınların doğumdan sonra çocuklarını bırakmalarını da öngörür hale gelmişti (Bynum, 2012, s. 167).

8 Bir bulaşıcı hastalığın enfekte olmuş konakçı, vektör gibi aracılardan başka canlılara geçmesi. 
okullardaki bulaş yollarını engellemek için sağlıklı ve hasta çocukların birbirlerinden ayrılmalarının önemini vurguluyordu. Günümüzde aşikâr gelebilecek olan bu bilgi, toplumun önemli bir kısmının veremin hala irsi olduğunu düşündüğü 1920'li yıllarda, halkı veremin bulaşıcı, önlenebilir ve tedavi edilebilir bir hastalık olduğuna ikna etmeye çalışıldığını göstermektedir. Tevfik İsmail öncelikle düzenli taramalarla veremlilerin tespit edilip dışarıda tedavilerinin sağlanabilmesini, ayrıca öğrenciler için düzenli sağlık karnelerinin tutulmasını şart koşuyordu (1929, s. 7-8).

Veremin başlangıcına ilişkin istatistikler hekimlerin kendi klinik tecrübelerini doğrulayacak şekilde okul çağındaki çocukları işaret ediyordu. Ne var ki veremin teşhisinde hekimler yine de zorlanıyordu. Bu durumun sebebi, hastalığın ilk evresinin genellikle basit soğuk algınlıklarıyla karıştırılarak ciddiye alınmaması ve hekime başvurulmamasıydı. Bahsedilen sorunu aşmanın yolu düzenli taramalar, sıhhi kongreler ve çocukların basit şikâyetlerinin ciddiye alınmasından geçiyordu (Doktor Fazıl Şerafeddin, 1930, s. 2-3).

1920'ler ile 1950'ler arasında Fransa, Almanya ve İskandinav ülkelerinin başını çektiği pek çok ülkede aşı kampanyaları yoluyla çocuklar B.C.G. aşısı yapılmaya başlanmıştı (Bynum, 2012, s. 177-178). Elbette hastalıkla mücadelede B.C.G. aşısının önemi, yeni doğanlardaki etkisi dünyadan örnekler sunarak sıklıkla vurgulanmaktaydı (Doktor Fazıl Şerafeddin, 1932, s. 3-5; Doktor Zühtü Tevfik, 1933, s. 3-7; Tevfik Salim, 1933, s. 1-6). Aslında aşı konusundaki nasihat literatürü Edhem İbrahim Paşa’nın 1868 tarihli Terbiyet'ül-Etfal isimli eserinden beri mevcuttur (Okay, 1998, s. 66-67). Yine de erken Cumhuriyet dönemi aşı kampanyaları ve propagandalarının yoğunluğu ile karşılaştırıldığında Osmanlı dönemi propagandalarının sıradan insanlara yoğun şekilde ulaştığını düşünmek güç olabilir. Keza, erken Cumhuriyet döneminde dahi propagandanın ne kadar etkili olduğu tartışmaya açıktır.

Vereme maruz kalmaları daha yoğun olduğundan çocukların hastalıktan korunmalarını sağlamak için sağlık propagandası faaliyetleri yürütmek en baştan beri temel yöntemlerden biri olmuş, çocuklara yönelik yayınlar geç Osmanlı döneminden itibaren yaygınlaşmaya başlamıştı. 1896 tarihinden itibaren çıkarılmaya başlanan Çocuklara Mahsus Gazete gibi yayınlarda konu ile ilgili çok sayıda yazı mevcut olmakla beraber yayın türü gazete ile sınırlı değildi, aynı zamanda telif ve tercüme eserler kaleme alıniyordu (Okay, 1998, s. 67-72).

Bu eserlerden bir tanesi de "Çocuk Sahifeleri" idi. Yaşamak Yolu, 1929-1972 yılları arasında düzenli olarak çıkmış olan bir propaganda dergisiydi ve İstanbul Verem Savaşı Derneği'nin yayın organıydı (İlikan Rasimoğlu, 2014; 2017). 3.000 tirajı olan derginin içinde Çocuk Sahifeleri başlı̆ı̆ını taşıyan, ayrı numaralandırılan ve büyük ihtimalle derginin içinden kopartılıp okumaları içinde çocuklara verilmesi tasarlanan bir bölüm bulunmaktaydı. Çocuk Sahifeleri'nde çocuklara yönelik piyesler, hikâyeler, bulmacalar 
ve çizimler bulunmaktayd1. ${ }^{9}$ Ekin içeriğinin temel odak noktası, verem özelinde olsun veya olmasın çocukların sağlık kurallarına uygun olarak hareket etmeleri, her şeyden önce hijyen konusundaki bilgilerin ve davranış kalıplarının geliştirilmesiydi. ${ }^{10}$ Özellikle 1929 İktisadi Buhranı'ndan sonra çocukların yardım sandıkları, Çocuk Esirgeme Kurumu gibi kurumlara yardım etmelerine teşvik edilmesi, Cumhuriyetin krizi sonrasında görülen yoksulluğu azaltma çabasının uzantısı olarak görülebilir (Öztan, 2012, s. 116-125).

Çocukların içinde rol alabileceği eğitici oyunlarının amacı, çocuklardan okul öğretmenlerine kadar herkesi bir arada toplamak ve sosyal faaliyetlerde buluşturmaktı (Öztan, 2012, s. 67). Örneğin, 1929 tarihli bir piyeste çocuklar için bir "sıhhatler diyarı" tasavvur edilmekte ve o diyarda çocukların hep neşeli ama aynı zamanda "ahlaklı" oldukları düşünülmekteydi. Oyunda cehalet, ahlak gibi çeşitli vasıflar kişileştirilmekte, "cehalet" el ele tutuşarak kendilerini bilgilendiren "terbiye"ye doğru yürüyen çocukların yolunu kesmeye çalışmaktaydı. "Terbiye" "temizlik"i yardıma çağırıp sıhhatle diyarına gidebilmek için diş firçalamak, banyo yapmak gibi alışkanlıkların gereklerini anlatmaktaydı. Nihayetinde "kirlilik" artık çocuklara etki edemeyeceğini anlayarak onların yanından uzaklaşmaktaydı (Tevfik İsmail, 1929a, s. 1-2). Burada anlatılan hikâye, sağlık ile iyi ahlak ve gündelik alışkanlıklar arasında bağ kurmayı öngörmekteydi.

Derginin aynı sayısında çeşitli seviyelerdeki okullara devam eden çocuklara yönelik bir anket yapılarak verem hakkındaki bilgileri tespit edilmeye çalışılmıştır. Her ne kadar çocukların verdikleri söylenen cevaplar mevcut bilgiden ziyade edinilmiş olması beklenen bilgileri içerdiği izlenimi verse de, söylemsel açıdan böyle bir anketin varlığı önemlidir. On dört yaşındaki Vehip Efendi'nin ağzından İstanbul'da senede ortalama 3-4 bin kişinin veremden öldüğü bilgisi verilmekte ve hastalığın bulaşıcı doğası ile korunma yolları, verem hastane ve dispanserleri için para toplanmasının önemi anlatılmaktadır. Dokuz yaşındaki Haluk Efendi ise verem mikroplarının bulaşma yollarını anlatıyor ve yere tükürülmemesi gerektiği yönündeki öğüdü dergide "Biz de yere tükürmeyelim" şeklinde büyük harflerle yer alıyordu (Yaşamak Yolu, 1929, s.2).

Kadıköy Erkek Orta Mektep son sınıf öğrencisi olan on yedi yaşındaki Hamit, veremin ülkede çok tahribat yapan bir hastalık olduğunu söyleyerek o da bulaşma yolları hakkında çocuk sayfaları için detaylı sayılabilecek bilgiler vererek veremden korunmanın tek çaresinin hıfzıssıhha kurallarına uymak olduğunu anlatıyordu. Veremli ebeveynlerden doğan çocuğun bilimsel ve hijyenik bakım ile hastalıktan kurtulabileceği anlatılıyordu. Aynı okulun üçüncü sınıf öğrencisi Hasan Fehmi ise veremin daima zayıf olanlara bulaştığını söylüyordu (Yaşamak Yolu, 1929, s. 3-4). Hasan Fehmi'nin

9 Piyeslerin bir kısmında, "Léon Labry’den aktaran Tevfik İsmail” ibaresi bulunmaktaydı.

10 Yaşamak Yolu Maarif, Harbiye gibi vekâletlere dağıtılmaktaydı, dolayısıyla zaten öncelikle öğretmen, bürokrat ve subay çocukları okuyabildiği varsayımını göz ardı etmemek gerekmektedir. 
sözlerinden zayıflığın toplumsal koşulara işaret etmediği anlaşılmaktadır. Zayıf olmak, bireyin kendi sorumluluğu olarak tahayyül edilmektedir. Genellikle hijyen kurallarına uymak, sağlıklı yaşamak, bunun için iyi beslenip açık havada bulunmak ve bedenine iyi bakmak çocuklar için de birer görev olarak tanımlanmış; dahası, çocuklara ulaşılarak yetişkinlerin de sağlık davranışlarını değiştirmeleri hedeflenmişti.

Verem olmak, belirli davranış kalıplarının tekrarlanmasından kaçınmanın doğal sonucu olarak sunuluyor ve edeple davranış kalıpları bir tutuluyordu. Yerlere tükürmemek, burundan nefes almak, insanların yüzüne karşı öksürmemek, toz kaldırmamak, evleri havalandırmak, yatarken pencereleri açık tutmak gibi davranışlara yönelik öğütler dergide sloganlaştırılıyor ve büyük harflerle, resim altı yazısı haline getiriliyordu. Lamia isminde bir kız dadısının saçını taramasına engel olmakla başlayan "içtimâi vazifesini" aksatma eylemini yine başkasının yemeğini yemekle temsil edilen sağlık bilgisi kurallarını ihlal ile devam ettiriyor, bu süreçte kendisinden beklenen uyumlu davranışları sergilemiyor ve sonunda hastalanıyordu. Kendisine verem başlangıcı koyan hekimler bu defa tam itaat bekliyor Lamia ise ancak bu şartlara uyarak tamamıyla iyileşebiliyordu. Bu hikâyede uyumsuz birey ve uyumsuz hasta davranışları birbirleriyle özdeşleştiriliyor ve bu davranışların sonucu olarak bulaşıcı hastalık gösteriliyordu (Tevfik İsmail, 1929b, s.1-2).

Çocuk Sahifeleri'nde "Mikroplar" isimli oyunda odayı havalandıran ve ilaçlı su ile silen bir çocuğun davranışı "bir vazife-i içtimâiye yapıyor, bizde ve etrafımızda kümelenen mikropları öldürüyor" şeklinde tanımlanıyordu (1929, s. 3). B.C.G. aşısının koruyuculuğunu anlatmak için çocukların oynaması tasarlanan kısa piyes de yer almış ve burada hem Validebağ Prevantoryumu ve Heybeliada Sanatoryumu hem de B.C.G. aşısı tanıtılmış ${ }^{11}$, sonuçta her yeni doğanın aşılanması ile verem hastalığının önünün alınabileceği ifade edilmişti (Tevfik İsmail, 1930a, s. 1-4). “Emine'nin Tükürüğü̈" isimli hikâyede "başkalarının pisliklerinden kendimizi muhafaza etmek" salık veriliyor (Yaşamak Yolu, 1930, s. 3), dolayısıyla halk sağlığının temel kuralı anlatılıyordu.

Validebağ Prevantoryumu'ndaki veremlilerin yalnız bedenleri değil ruhlarının da iyileştirilmesi gerektiğine dair hikâyeler de bulunmaktaydı. Prevantoryumdaki çocuklar yoksul ailelere mensuptu ve aileleri uzun saatler çalışmak zorunda olduklarından ziyaretçileri olmuyordu. Hikâyede bu çocuklara manevi anlamda destek olunması gerektiği, mektup arkadaşı olunması, okunmuş gazete ve dergilerin onlara gönderilmesi teşvik ediliyordu. Prevantoryumda eğitimler, konferanslar veriliyor, çocuklar okuma yazma öğreniyor, dil, hesap, hıfzıssıhha dersleri görüyorlardı. Bu dersler hem ulusal

11 B.C.G. aşısının Türkiye'de uygulanması Bakteriyolojihane Müdürü Refik Güran'ın girişimiyle gerçekleşmişti. Aşının Türkiye'de üretilebilmesi için Yaşamak Yolu'nda Tevfik Sağlam konu üzerinde yazılar yazmış, 17 Mayıs 1928 tarihinde aşı, serum ve benzeri malzemeleri yapmak ve ülkeye giren ilaçları kontrol etmek üzere "Merkez Hıfzıssıhha Müessesesi” kurulmuş, 1931 senesinde aşı ülkede üretilmeye başlanmıştı (Özaydin, 1999, s. 196-201). 
eğitim, hem hijyen eğitiminin bir parçası olarak, hem de meşguliyet tedavisi olarak tasarlaniyordu (Tevfik İsmail, 1930b, s. 2).

Dergideki örneklerden de görüleceği üzere Çocuk Sahifeleri’nde derginin yetişkinlere ayrılan kısmında bulunan savaş ve kahramanlık hikâyelerine yer verilmemekte, toplumsal cinsiyete ilişkin belirgin bir söylem üretilmemekte, hatta "mikroplara galebe çalınız" gibi ifadelerin dışında militarist söylem de bulunmamaktaydı. Onun yerine sosyal yardıma, gönüllüğe ve hijyen kurallarına yönelik bir vurgu bulunmaktaydı. Yine de hijyen kurallarının aktarılma biçimi toplumsal görev ile ilişkilendirilmekte ve hem akran hem de yetişkinlere bu kuralların çocuklar tarafından öğretilmesine odaklanmaktaydı. Sağlık konusunda bilgili olmak bir görevi ifa etmek olduğundan ahlaklılık ile bir tutuluyor ve çocuklara kendi akranlarından rol modeller üretiliyordu.

\section{Tartışma ve Sonuç}

Erken Cumhuriyet döneminde nüfus politikaları pronatalizmi destekleyecek yönde şekillenmişti ve bu politikalar başta hekimler olmak üzere dönemin eğitimli elitlerinin desteğiyle uygulanabilmişti. Veremle Mücadele Derneği'nin yıllık kongrelerinin Türk Ocağı'nda, Ulusal Tıp Kongrelerinin ise Meclis binasında yapıldığı düşünülürse, hekimlerin önerilerinin idari kadrolar tarafından mümkün mertebe yerine getirilmesine özen gösterildiği düşünülebilir.

Hekimler ve bürokratlar ülkede bir sağlık sisteminin geliştirilmesi kadar, sağlık propagandasının da salgın hastalık ve çocuk ölümleri sorunlarının önünü alabileceğini düşüncesiyle propagandaya önem vermişlerdi. Fakat sağlık propagandası salt sağlığa ilişkin olmaktan ziyade aynı zamanda uluslaşmanın içkin bir parçası olarak tahayyül edilen medenileşme projesinin gerçekleşmesi için üretilen söylemleri de içeriyordu. Diğer bir deyişle, sağlıklı olacak şekilde davranabilmek aynı zamanda sorumlu bir vatandaştan beklenen temel becerilerden biri haline geliyordu.

Bu dönüşümü mümkün kılan tıbbi, bilimsel ve politik olmak üzere üç unsur bulunmaktaydı. Tıbbi olarak sıhhi şartlara bağlı olan halk sağlı̆̆ı anlayışından kişisel hijyene dayalı halk sağlığı anlayışına geçilmişti. Yeni halk sağlığı uygulamaları bulaşıcı hastalık tehlikesini belirli bir bölgeden alıp her yere yayıyordu, bu nedenle tıbbi bilginin erişebileceği alan da sınırsızlaşıyordu. Sınırsızlaşan tehlike alanında gözetim ve müdahale ise yeni idari teknikleri ve söylemleri içeriyor, dolayısıyla vatandaşlık eğitimi sağlık eğitiminin parçası haline gelebiliyordu.

İkinci ve bilimsel olarak, bir önceki yüzyılda üretilmiş olmasına rağmen mikrop teorisi ancak 20. yüzyılda yaygınlaşabilmiş ve hijyen uygulamalarının toplumun tüm katmanlarına aktarılmasının bir hedef haline gelmesi mümkün olabilmişti. Mikropların 
varlığ verem hastalığında olduğu gibi hastalıktan korunmak için kişisel hijyen kurallarına uyulmasına yönelik telkinlere bilimsel dayanak sağliyor ve bu telkinleri meşrulaştırıyordu. Böylelikle hastalığın toplumsal sebepleri görünmez kılınıyor ve veremle mücadelenin önemli bir kısmı devletin veremin ortaya çıkışını ve bulaşmasını kolaylaştıran barınma, beslenme gibi yaşam koşullarını iyileştirmeye ilişkin politikalar üretmesine dair sorumluluğunu bireye ve gönüllü derneklere aktarılabiliyordu.

Üçüncü ve politik olarak, milliyetçi propaganda ile sağlık propagandasının örtüşmesinin tarihsel bir altyapısı vardı. 19. yüzyıldan beri yaşanan nüfus azlığı iki savaş arası dönemde güvenlik ve işgücü eksikliği açısından somut bir sorun olarak yönetici elitlerin çözmesi gereken önemli bir mesele olarak görülüyordu. Demografik dönüşüm ile beraber yaşanan kültür krizinin aile, eğitim gibi temel kurumlarda yarattığ 1 değişim sonrası bu kurumların restorasyonu için ihtiyaç duyulan teknik bilgiye haiz olmaları nedeniyle hekimler bir iktidar alanı bulmuşlardı.

Bu bağlamda nüfus ve kültür krizlerinin çözümü yeni aile ve yeni kadını beraberinde getirmiş ve aynı zamanda vatandaş çocuk anlayışına dayalı bir dil üretmişti. Sağlıklı çocuk, rejimin ve ulusun devamlılığının teminatı anlamına gelmekteydi. Pronatalist politikalar öjeniyle birleşmekte, en azından hekim ve bürokratların gözünde ırkın bozulması anlamında kullanılan dejenerasyondan duyulan korku bir dava haline gelmekteydi. Sadece çocuk düşürenler değil aynı zamanda çocuklarına medeni ve sıhhi davranışları öğretemeyenler de vatani görevini yapmamaktan katilliğe uzanan bir skalada suçlanmışlardı. Verem söz konusu olduğunda da hem yetişkinlerin çocukları hem de çocukların yetişkinleri eğitmesi bekleniyordu. Böylelikle halihazırdaki ya da gelecekteki yetişkinlerin düzgün bedenli, sağlıklı zihinli, iyi ahlaklı ve medeni birer vatandaş haline gelmeleri tasarlanıyordu.

Hastal1kla mücadelenin toplumsal ve politik veçhelerini vurgulamak, veremle mücadelede büyük adımların atılmasını sağlamadığını iddia etmek anlamına gelmemektedir. Özellikle antibiyotiklerin henüz bilinmediği, hastalıkla mücadelenin ancak dispanser, sanatoryum gibi kurumlarda gerçekleştirilebildiği ve bu kurumların henüz yetersiz olduğu bir dönemde hekimlerin kullanabileceği muhtemelen en etkili yöntem bireylere hastalıktan korunmanın yollarını öğretmekti. Aynı zamanda halk sağlığı uygulamalarının temel varlık ve etkinlik sebebinin tedavi değil korunma olduğu vurgulanmalıdır; bu durumda propagandanın sağlık okuryazarlığına doğru atılan ilk adım olduğu söylenebilir.

Ne var ki, söz konusu durumda propagandanın amacı sadece hastalıklardan korunma değil aynı zamanda toplumsal ve politik kodların iletilmesidir. Nihayetinde 19. yüzyılın başlarında bir biyolojik sorun olan çocuk sağlığı alanı, yüzyıl sonuna gelindiğinde toplumsal, Cumhuriyet ile beraber ise ulusal bir sorun haline gelmiş, böylelikle gözetim ve müdahale alanına dönüşmüştü. Hem kişisel hijyen ile beraber sağlığın korunması hem de adap 
aracılığıyla medeni davranış kodlarının oluşturulması, hekimlerin üzerine konuşacağı, tayin ve müdahale edeceği, gerektiğinde düzelteceği gündelik alışkanlıklara dönüşmüş, böylelikle yetişkinlerin ve çocukların gündelik hayatları yönetilmeye başlanmıştı.

Teşekkür: Çocukluk çalışmaları alanına ilişkin sorularımı sabırla cevaplayan ve güncel kaynakları benimle paylaşan Deniz Arzuk ile makaleyi titizlikle okuyarak yorum ve önerileriyle katkıda bulunan özel sayı editörü Mehmet Fatih Aysan'a teşekkür ederim.

Hakem Değerlendirmesi: Dış bağımsız.

Çıkar Çatışması: Yazar çıkar çatışması bildirmemiştir.

Finansal Destek: Yazar bu çalışma için finansal destek almadığını beyan etmiştir.

Peer-review: Externally peer-reviewed.

Conflict of Interest: The author has no conflict of interest to declare.

Grand Support: The author declared that this study has received no financial support.

\section{Kaynakça/References}

Akın, Y. (2014). Gürbüz ve yavuz evlatlar: Erken Cumhuriyet'te beden terbiyesi ve spor [Robust and resilient children: Physical education and sports in the early republic]. İletişim Yayınları.

Aksu, M. (2007). Tıp tarihi açısından Türkiye'de verem savaşı [The struggle against tuberculosis in Turkey from the perspective of medical history]. Ankara: Türkiye Ulusal Verem Savaş1 Dernekleri Federasyonu.

Alanen, L. (2009). Generational order. In J. Qvortrup \& W. Corsaro (Eds.), The Palgrave handbook of childhood studies (pp. 159-174). London, UK: Palgrave Macmillan.

Araz, Y. (2013). 16. yüzyıldan 19. yüzyıl başlarına: Osmanlı toplumunda çocuk olmak [From the 16th to the early 19th centuries: Being a child in Ottoman society]. Kitap Yayinevi.

Ariès, P. (1962). Centuries of childhood: A social history of family life (R. Baldick. Trans.). New York, NY: Alfred A. Knopf.

Armstrong, D. (1986). The invention of infant mortality. Sociology of Health \& Illness, 8(3), 211232. doi: 10.1111/j.1467-9566.1986.tb00298.x

Armstrong, D. (1993). Public health spaces and the fabrication of identity. Sociology, 27(3), 393-410. doi: $10.1177 / 0038038593027003004$

Aysan, M. F. (2014). Türkiye'nin demografik dönüşümü ve yeni meydan okumalar. In L. Sunar (Ed.), Türkiye'de toplumsal değişim [Social change in Turkey] (1st ed., pp. 67-87). İstanbul: Nobel Akademik Yayıncilık.

Balsoy, G. E. (2015). Kahraman doktor ihtiyar acuzeye karşı: Geç Osmanlı doğum politikaları [The hero doctor versus the old crone: Late Ottoman birth policies]. Can Yayınları.

Başboğa, S. (2017). Annelik sanatı: Erken cumhuriyet dönemi çocuk dergilerinde çocuğun bedensel kurgusu [The art of motherhood: The bodily fiction of children in child magazines of the Early Republic Period]. Insan ve Insan, 4(12), 6-30. doi: 10.29224/insanveinsan.313009

Başboğa Özen, S. (2019). Erken cumhuriyet dönemi çocuk yayınlarında çocuklara yönelik adab-1 muaşeret, görgü ve nezaket kuralları [Forms of politeness, etiquette and rules of good manners for children in children's publications from the Early Republican Period]. Hacettepe Üniversitesi 
Cumhuriyet Tarihi Araştırmaları Dergisi, 15(29), 59-86. Retrieved from http://www.ctad. hacettepe.edu.tr/15_29/03-basboga050719.pdf

Black, E. (2003). War against the weak: Eugenics and America's campaign to create a master race. New York, NY: BMJ Publishing.

Brady, G., Lowe, P., \& Olin Lauritzen, S. (2015). Connecting a sociology of childhood perspective with the study of child health, illness and wellbeing: Introduction. Sociology of Health \& Illness, 37(2), 173-183. doi: 10.1111/1467-9566.12260

Burgaç, M. (2011). Cumhuriyet döneminde Trakya'da örnek bir sağlık kampı uygulaması: Azat obalar1 [A sample health camp application in Thrace during the Republic Period: The Azat Camps]. Atatürk Araştırma Merkezi Dergisi, 27(81), 651-672. Retrieved from https://dergipark.org.tr/tr/ pub/aamd/issue/44065/542964

Bynum, H. (2012). Spitting blood: The history of tuberculosis. Oxford, UK: Oxford University Press.

Carlson, E. A. (2011). The Hoosier connection: Compulsory sterilization as moral hygiene. In P. E. Lombardo (Ed.), A century of eugenics in America: From the Indiana experiment to the human genome era (pp. 11-25). Bloomington, IN: Indiana University Press.

Carter, S. (2012). The medicalization of sunlight in the early twentieth century. Journal of Historical Sociology, 25(1), 83-105. doi: 10.1111/j.1467-6443.2011.01405.x

Corsaro, W. A. (2015). The sociology of childhood. Newbury Park, CA: Sage Publications.

Çiçek, N. (2012). Erken cumhuriyet döneminde modern çocukluk nosyonunun görünümleri üzerine bir analiz [An analysis over the views on the notion of modern childhood in the Early Republican Period]. Mülkiye Dergisi, 36(4), 69-104. Retrieved from https://dergipark.org.tr/tr/pub/mulkiye/ issue $/ 1 / 8$

Çocuk Sahifeleri. (1929). Mikroplar [Microbes]. Yaşamak Yolu, 2, 3-4.

Çocuk Sahifeleri. (1930). Emine'nin tükürüğü [Emine’s saliva]. Yaşamak Yolu, 22, 3-4.

Demir, İ. O. (2019). Sanatoryumdan akıl hastanesine: Erenköy Sağllk Yerleşkesi'nin tarihi (19322018) [From sanatorium to mental hospital: History of Erenköy Health Campus] (unpublished master's thesis). İstanbul Bilgi Üniversitesi Sosyal Bilimler Enstitüsü Kültürel İncelemeler Yüksek Lisans Program1, İstanbul.

Doktor Ali Rifat. (1933). Nüfus tenakusu ve çocuk ölümlerinin başlica sebepleri ve çareleri [The major causes of and remedies for population decrease and child deaths]. Gürbüz Türk Çocuğu, 75, 6-13.

Doktor Behçet. (1929). Çocuk bakımı [Childcare]. Cidal, 5(12), 3.

Doktor Fazıl Şerafeddin. (1930). Verem mücadelesinde mektep hekiminin mühim vazifesi [The important duty of the school physician in the fight against tuberculosis]. Yaşamak Yolu, 21, 2-3.

Doktor Fazıl Şerafeddin. (1932). B.C.G. aşısının çocuk ölümü ile mücadelesindeki ehemmiyeti [The importance of the BCG vaccine in the fight against child death]. Yaşamak Yolu, 37, 3-5.

Doktor Kudsi. (1934). Himaye-i etfal nedir? Ve himaye-i etfalin moderne technique'i [What is children's protection? And the modern techniques of children's protection]. Yaşamak Yolu, 63, 2-4.

Doktor Süleyman Edhem. (1929). İçtimai bir vazife, çocukların veremden vikayesi [A social duty, children's protection from tuberculosis]. Yaşamak Yolu, 3, 5-6.

Doktor Tevfik İsmail. (1929). Verem ve muallimler [Tuberculosis and teachers]. Yaşamak Yolu, 3, 7-8.

Doktor Zühtü Tevfik. (1933). Verem mücadelesinde B.C.G. aşısının ehemmiyeti [The importance of the BCG vaccine in the struggle against tuberculosis]. Yaşamak Yolu, 49-50, 3-7. 
Doktorlarımıza göre doğumlar ve çocuk ölümleri [Births and Child deaths according to our doctors] (1935). Gürbüz Türk Çocuğu, 104, 22-25.

Duben, A., \& Behar, C. (2013). İstanbul haneleri: Evlilik, aile ve doğurganlık 1880-1940 [Istanbul households: Marriage, family, and fertility]. Istanbul: Boğaziçi Üniversitesi Yayınları.

Düzcü, L., \& Sezer, C. (2016). Doktor Besim Ömer ve Dokuzuncu Washington Konferansı [Dr. Besim Ömer and the 19th Washington Conference]. Ankara: Türk Kızılayı Yayınları.

Erdal, İ. (2011). Ülkü mecmuasına göre erken Cumhuriyet dönemi nüfus politikası (1923-1938) [Population policy in the Early Republican Period according to Ülkü magazine]. Ankara Üniversitesi Türk İnkllap Tarihi Enstitüsü Atatürk Yolu Dergisi, 12(48), 779-790. doi: 10.1501/ Tite_0000000345

Glenn, E. N. (1994). Social constructions of mothering: A thematic overview. In E. N. Glenn, G. Chang, \& L. R. Forcey (Eds.), Mothering: Ideology, experience and agency (pp. 1-29). Abingdon, UK: Routledge.

Gökçe, T. İ. (1957). Heybeliada Sanatoryomu: Kuruluş ve gelişimi, 1924-1955 [Heybeliada Sanatorium: Establishment and development]. İstanbul: İsmail Aygün Matbaası.

Gökçe, T. İ. (1969). Verem Savaşı'nda 50 y1l: 1918-1968 [50 years in the war against tuberculosis]. Yaşamak Yolu, 394-396, 16-19.

Gürsoy, A. (1995). Child mortality and the changing discourse on childhood in Turkey. In E. W. Fernea (Ed.), Children in the Muslim Middle East (pp. 199-222). Austin, TX: University of Texas Press.

Hendick, H. (1994). Child welfare: England 1872-1989. Abingdon, UK: Routledge.

Hendrick, H., Horn, P., \& Harry, H. (1997). Children, childhood and English society, 1880-1990 (Vol. 32). Cambridge, UK: Cambridge University Press.

Hilmi, Prof. Dr. İ. (1934). Çocuk bakımının ehemmiyeti [The importance of childcare]. Yaşamak Yolu, 61, 1-5.

İlikan Rasimoğlu, C. G. (2012). Tuberculosis, medicine and politics: Public health in the Early Republican Turkey. Saarbrucken, Germany: Lambert Academic Publishing.

İlikan Rasimoğlu, C. G. (2014). A sanitary journal for common people: Yaşamak Yolu. In İ. İlkılıç, H. Ertin, R. Brömer, \& H. Zeeb (Eds.), Health, culture and the human body: Epidemiology, ethics and history of medicine, perspectives from Turkey and Central Europe (pp. 299-311). İstanbul: Betim Center Press.

İlikan Rasimoğlu, C. G. (2017). "Memlekete çok çocuk ve sağlam çocuk lazımdır”: Erken Cumhuriyet Dönemi'nde verem mücadelesi ve Yaşamak Yolu dergisi [Many children and sturdy children are needed in the country: The struggle against tuberculosis in the Early Republican Period and Yaşamak Yolu magazine]. In B. Kurt \& İ. Yaşayanlar (Eds.), Osmanlı'dan Cumhuriyet'e salgın hastalıklar ve kamu sağllğ (pp. 193-214). Tarih Vakfı Yurt Yayınları.

İlikan Rasimoğlu, C. G. (2018). "Verem iyi olur bir hastalıktır”: Cumhuriyetin ilk yıllarında verem mücadelesi ve siyaset [Tuberculosis is a curable disease: The struggle against tuberculosis and politics in the first years of the Republic]. Toplumsal Tarih, 296, 86-96.

James, A., Jenks, C., \& Prout, A. (2007). Theorizing childhood. Cambrige, UK: Polity.

Kahya, E., \& Erdemir, A. D. (2000). Bilimin ışığında Osmanlıdan Cumhuriyete tıp ve sağlık kurumları [Medicine and health institutions from the Ottomans to the Republic in the light of science]. Ankara: Türkiye Diyanet Vakfi Yayınları. 
King, L. (2016). Future citizens: Cultural and political conceptions of children in Britain, 1930s-1950s. Twentieth Century British History, 27(3), 389-411. doi: 10.1093/tcbh/hww025

Kline, W. (2001). Building a better race: Gender, sexuality, and eugenics from the turn of the century to the baby boom. Berkeley, CA: University of California Press.

Mazhar, O. (1933). Cumhuriyetin sihhat siyaseti [Health policy of the Republic]. In O. Mazhar (Ed.), Sihhat Almanakr. İstanbul: Kader Matbaas1.

Okay, C. (1998). Osmanlı çocuk hayatında yenileşmeler 1850-1900 [Novelties in Ottoman children's lives]. İstanbul: Kırkambar Yayınları.

Okumuş, B. T. (2017). Türkiye'de modernleşme ve propaganda: Yeni Cumhuriyet'i tanıtmak, La Turquie Kemaliste Dergisi (1934-1948) [Propaganda and modernization in Turkey: Presenting the New Republic in La Turquie Kemaliste magazine] (unpublished doctoral dissertation). İstanbul Bilgi Üniversitesi, İstanbul.

Özaydın, Z. (1999). Büyük önder Atatürk'ün himayelerinde yapılan 1. Milli Tıp Kongresi (1925) [The First National Medical Congress made under the auspices of the great leader Ataturk]. In III. Türk Tip Tarihi Kongresi Kongreye Sunulan Bildiriler (pp. 283-293), İstanbul 20-23 Eylül 1993. Ankara: Türk Tarih Kurumu.

Özkan, Dr. M. T. (1934). Çocukluğu koruma, maternité [Childhood protection, maternity]. Yaşamak Yolu, 70-72, 7-9.

Özkan, Dr. M. T. (1935). Bizde çocuk düşürme [Abortion in our country]. Yaşamak Yolu, 73-75, 18-19.

Özkan, Dr. M. T. (1937). Okulda tüberkülozdan korunma, 2. kısım [Protection from tuberculosis in school, pt. 2]. Yaşamak Yolu, 85, 5-9.

Öztan, G. G. (2012). Türkiye'de çocukluğun politik inşası [Political construction of childhood in Turkey]. İstanbul: İstanbul Bilgi Üniversitesi Yayınları.

Pinell, P. (1996). Modern medicine and the civilising process. Sociology of Health \& Illness, 18(1), 1-16. doi: 10.1111/1467-9566.ep10934402

Robertson, P. (2006). Home as a nest: Middle class childhood in nineteenth century Europe. In L. Rowman (Ed.), The history of childhood (pp. 407-431). London, UK: Littlefield Publishers.

Sağlık Türeleri. (1935). [Health rules].Yaşamak Yolu, 78, 6.

Schmidt, J. (2013). Children and the state. In P. S. Fass, (Ed.), The Routledge history of childhood in the Western world (pp. 174-190). Routledge.

Sears, A. (1992). 'To teach them how to live' the politics of public health from tuberculosis to AIDS. Journal of Historical Sociology, 5(1), 61-83. doi: 10.1111/j.1467-6443.1992.tb00023.x

Shorter, F. C. (1985). The population of Turkey after the War of Independence. International Journal of Middle East Studies, 17, 417-441. doi: 10.1017/S002074380002941X

Shorter, F. C. (2000). Turkish population in the great depression. New Perspectives on Turkey, 23, 103-124. doi: 10.1017/S089663460000340X

Sihhatimi Verem Mücadele Cemiyeti Kurtard1. (1934). [The society for the struggle against tuberculosis saved my health.] Yaşamak Yolu, 63-64, 1-3.

Stern, A. M. (1999). Responsible mothers and normal children: Eugenics, nationalism, and welfare in post-revolutionary Mexico, 1920-1940. Journal of Historical Sociology, 12(4), 369-397. doi: $10.1111 / 1467-6443.00097$

Şirin, F. S. (2013). İktidar ve çocuk [Power and children]. Turkish Studies, 8(8), 1275-1284. doi: 10.7827/TurkishStudies.5255 
Tanış, C. (2019). Türkiye'nin Sıhhi ve İçtimai Coğrafyası eserlerine göre verem hastalığının seyri [The course of tuberculosis according to Turkey's Sanitary and Social Geography Works]. OPUS Uluslararası Toplum Araştırmaları Dergisi, 11(18), 2832-2846. doi: 10.26466/opus.567455

Tekir, S. (2019). Erken Cumhuriyet dönemi Türkiye'de bulaşıcı hastalıklarla mücadele (1923-1930) [Combatting infectious diseases in Turkey in the Early Republican Period]. Atatürk Üniversitesi Türkiyat Araştırmaları Enstitüsü Dergisi, 65, 407-430. doi: 10.14222/Turkiyat4095

Tevfik İsmail (1929a). Çocuk sahifeleri: Sthhatler diyarında [Children's pages: In the land of health]. Yaşamak Yolu, 1, 1-2.

Tevfik İsmail (1929b). Çocuk sahifeleri: Lamia'nın başına gelenler [Children's pages: What happened to Lamia]. Yaşamak Yolu, 2, 1-2.

Tevfik İsmail (1930a). Çocuk Sahifeleri: Doktorun muayenehanesinde [Children's pages: In the doctor's office]. Yaşamak Yolu, 21, 1-4.

Tevfik İsmail (1930b). Çocuk sahifeleri: Halûkun hikâyesi [Children's pages: The story of Halukun]. Yaşamak Yolu, 24, 2-3.

Tevfik Salim (1929). Yaşamak yolu [The way of living]. Yaşamak Yolu, 1, 2-3.

Tevfik Salim (1933). B.C.G. aşısı [The BCG vaccine]. Yaşamak Yolu, 34, 1-6.

Thurer, S. (1995). The myths of motherhood: How culture reinvents the good mother. New York, NY: Penguin.

Toprak, Z. (2017). Erken cumhuriyet, kürtaj ya da 1skat-1 cenin [The Early Republic and Abortion]. Toplumsal Tarih, 282, 50-61.

Toprak, Z. (2017b). Türkiye'de yeni hayat: Inkılap ve travma 1908-1928 [New life in Turkey: Revolution and trauma]. Doğan Egmont Yayıncılık.

Tuğluoğlu, F. (2008). Cumhuriyetin ilk döneminde verem mücadelesi ve propaganda faaliyetleri [The battle with tuberculosis and propaganda activities in the first period of the Republic]. Yakın Dönem Türkiye Araştırmaları, 13-14, 1-26. Retrieved from http://dergipark.ulakbim.gov.tr/iuydta/ article/view/1023018785/10

Uludağ, O. Ş. (1934). Ben Verem Mücadele Cemiyeti azası oldum [I became a member of the Society for the Struggle against Tuberculosis]. Yaşamak Yolu, 70-72, 1-3.

Ulusun Çocuğu. ( 1935). Gürbüz Türk çocuğu [The robust Turkish child], 98, 13-16.

Vayre, P. (2007). Professeur Joseph Grancher (1843-1907). Centième Anniversaire de la mort d'un pasteurien convaincu. [Hundereth death anniversary of a convinced Pasteurian]. Retrieved from http://www.academie-medecine.fr/professeur-joseph-grancher-1843-1907-centieme-anniversairede-la-mort-dun-pasteurien-convaincu-2/

Verem (Tüberküloz). (1938). Sihhat ve İçtimai Muavenet Vekâleti Neşriyatından no. 60 [From the publications of the Ministry of Health and Social Affairs \#60]. Ankara Cezaevi Matbaası.

Yanıkdağ, Y. (2014). Millete deva olmak: Osmanlı savaş esirleri, tıp ve milliyetçilik [Healing the nation: Ottoman prisoners of war, medicine, and nationalism]. Tarih Vakfi Yurt Yayınları.

Yanıkdağ, Y. (2017). Psikopatlar, frengililer, veremliler ve mâderzâd caniler: Osmanlı'dan Cumhuriyet Türkiye'sine dejenerasyon korkusu [Psychopaths, Syphilitics, Tuberculars, and Born Criminals: Fear of Degeneration from the Ottoman Empire to the Turkish Republic] (pp. 47-70). In B. Kurt \& İ. Yaşayanlar (Eds.), Osmanlı'dan Cumhuriyet'e salgın hastalıklar ve kamu sağllğı. Tarih Vakfı Yurt Yayınları.

Yıldırım, N. (2010). Istanbul'un Sağllk Tarihi [A History of Healthcare in İstanbul]. İstanbul: İstanbul Üniversitesi, İstanbul 2010 Avrupa Kültür Başkenti Ajansı. 
